\title{
Ortaokul Öğrencilerinin Matematik Öz-yeterlik Algılarının ve Matematiğe Yönelik Tutumlarının İncelenmesi
}

\section{Investigating Mathematics Self-efficacy and Attitude Towards Mathematics of Middle School Students}

\begin{abstract}
Sevim SEVGI*, Zeynep YAKIŞIKLI**
Öz: $\mathrm{Bu}$ araştırmada ortaokul öğrencilerinin matematiğe yönelik tutumlarının ve matematik özyeterliklerinin cinsiyet, sınıf, okul, aylık gelir ve yazılı puanı değişkenlerine göre incelenmesi amaçlanmıştır. $\mathrm{Bu}$ doğrultuda nicel araştırma yöntemlerinden tarama modeli kullanılmıştır. Araştırma Kayseri ili Kocasinan ilçesinde bulunan A ortaokulu Kayseri ili İncesu ilçesinde bulunan B ortaokulu ve Kayseri ili Melikgazi ilçesinde bulunan C ortaokulu olmak üzere Milli Eğitim Bakanlığı'na bağlı üç farklı ortaokulda yapılmıştır. Araştırmaya 2019-2020 eğitim-öğretim yılı birinci döneminde okuyan 262 ortaokul öğrencisi katılmıştır. Araştırmada veri toplama aracı olarak Baykul (1990) tarafından geliştirilen Matematik Dersine Yönelik Tutum Ölçeği ve Umay (2001) tarafından geliştirilen Matematik Öz Yeterlik Algııı Ölçeği kullanılmıştır. Verilerin analizinde SPSS programıyla Mann Whitney U analizi, Kruskal-Wallis analizi, Tek Yönlü Varyans analizi (ANOVA) ve Spearman Brown analizi yapılmıştır. Araştırma sonucunda ortaokul öğrencilerinin matematik öz-yeterliklerinin cinsiyet, sınıf, okul, aylık gelir ve yazılı puanı değişkenlerine göre istatistiksel anlamda bir farklılık bulunmamıştır. Ortaokul öğrencilerinin matematiğe yönelik tutumlarında ise sınıf, okul ve aylık gelir değişkenine göre istatiksel olarak anlamlı farklılık bulunmuştur ancak cinsiyet ve yazılı puanı değişkenine göre istatistiksel olarak anlamlı farklılık bulunmamıştır. Spearman Brown analizi sonucunda matematiğe yönelik tutum ile matematik öz-yeterlik arasında anlamlı bir ilişki bulunmamıştır.
\end{abstract}

Anahtar Kelimeler: Matematiğe yönelik tutum, matematik öz-yeterlik, ortaokul öğrencileri

\begin{abstract}
In this study, it is aimed to analyze middle school students' attitudes towards mathematics and their mathematics self-efficacy according to gender, grade level, school, monthly income and exam scores. Survey model, one of the quantitative research methods, was used. The research was carried out in three different middle schools of the Ministry of National Education. Middle school A located in Kocasinan at Kayseri, middle school B located in İncesu at Kayseri and middle school C located in Melikgazi at Kayseri. 262 middle school students were studying in the first semester of 2019-2020 academic year participated in the study. The Attitude Scale for Mathematics developed by Baykul (1990) and the Mathematics SelfEfficacy Perception Scale developed by Umay (2001) were used as data collection tools. Mann Whitney U analysis, Kruskal-Wallis analysis, One Way Variance analysis (ANOVA) and Spearman Brown analysis were run by SPSS. As a result of the research, there was no statistically significant mean difference in the mathematics self-efficacy of middle school students according to gender, grade level, school, and monthly income. In the attitudes of middle school students towards mathematics, a statistically significant mean difference was found according to grade level, school and monthly income, but no significant mean difference was found according to gender and exam scores. As a result of the Spearman Brown analysis, there was no statistically significant relationship between attitude towards mathematics and mathematics self-efficacy.
\end{abstract}

Keywords: Attitude towards mathematics, self-efficacy, middle school

\section{Giriş}

Matematiği anlamlı öğrenmeye ve yaşantımızda etkili kullanmaya yönelik temel beceriler Milli Eğitim Bakanlığı (MEB) tarafından 2018 yılında güncellenen ortaokul matematik öğretim

\footnotetext{
* Dr. Öğr. Üyesi, Erciyes Üniversitesi, Eğitim Fakültesi, Kayseri-Türkiye, ORCID: 0000-0002-6611-5543, e-posta: sevimsevgi@erciyes.edu.tr

** Yüksek Lisans Öğrencisi (Matematik Öğretmeni), Erciyes Üniversitesi, Eğitim Bilimleri Enstitüsü, KayseriTürkiye, ORCID: 0000-0001-6487-5621,e-posta: zynp.yksk1@gmail.com
} 
programında belirlenmiştir (MEB, 2018). Öğrencilerin temel becerileri kullanarak matematiksel kavramları etkili bir şekilde kazanması amaçlanmaktadır. Bu temel becerileri: problem çözme, akı1 yürütme, ilişkilendirme, iletişim ve duyuşsal beceriler olarak belirlenmiştir. Duyuşsal beceriler ise öğrencilerin matematiğe yönelik olumlu tutum geliştirmeleri, öz güven sahibi olmaları, matematiksel değerlere sahip olmaları, öz düzenleme becerileri ve öz-yeterlik becerileri olarak tanımlanmıştır (MEB, 2018). Bu araştırmada duyuşsal becerilerden matematiğe yönelik tutum ve matematik öz-yeterlik becerisi birlikte incelenmiştir. Matematik öğretiminde yapılan araştırmalarda bu duyuşsal beceriler genellikle ayrı ayrı incelenmiştir. Bu çalışmada tutum ve özyeterlik birlikte incelenerek matematik alanyazımına katkı sağlanacağı düşünülmektedir.

Duyuşsal becerilerden tutum psikolojide "verilen bir objeye dair hoşa giden veya gitmeyen tepki vermede yatkınlık" şeklinde tanımlanmıştır (Hart, 1989, s. 39, Akt: Ural, 2007, s. 68). Yenilmez ve Özabacı (2003) tutumu öğrencinin etrafındaki kişilere veya nesnelere yükledikleri anlam, inanç ve oluşturdukları bakış açısı olarak tanımlamıştır. Benzer şekilde Yıldız (2006) tutumu kişinin geçmiş yaşantı ve tecrübeleriyle bir olaya ya da duruma karşı oluşturduğu inanç ve davranışa hazırlayan eğilim olarak açıklamıştır. Taşdemir'e (2009) göre tutum nispeten düşünceye dayanır nispeten de psikolojiktir; fakat doğuştan kazanılmaz yaşantı yoluyla elde edilir.

Tutumun çok farklı tanımları yapılmıştır. Yapılan genel tanımlardan ayrıca Neale (1969) matematiğe yönelik tutumu matematiği sevip sevmeme, matematik etkinliklerini kullanma veya kaçınma eğilimi, matematiğin iyi veya kötü olduğu düşüncesi, matematiğin yararlı olduğu veya işe yaramaz olduğu inancı olarak tanımlamıştır. Bu tanımdan anlaşılacağı gibi matematiğe yönelik tutum da matematiğe karşı öğrencinin eğilimleri yani matematikten hoşlanıp hoşlanmamaları ile ilgili olduğu söylenebilir. Matematik öğretiminde öğrencilerin matematiğe yönelik tutumu çok önemlidir (Zan ve Martino, 2007). Çünkü öğrenilen bilgilerin unutulmaması ve günlük hayata transfer edilebilmesi tutuma bağlıdır (Tan, 2015). Öğrenciler matematiğe yönelik olumsuz tutum oluşturduklarında matematikle ders dışında ilgilenmezler ve günlük hayatta kullanmazlar (Akdemir, 2006). Bu yüzden öğrencilerin matematiğe yönelik olumlu tutum geliştirmeleri gerektiği söylenebilir. Öğrenciler matematiğe karşı olumlu tutum geliştirdiklerinde matematik öğrenmeye hazır hale gelirler (Alkan, Güzel ve Elçi, 2004; Akt: Tan, 2015). Öğrencilerin matematiğe karşı olumlu tutum geliştirmeleri için gerekli olan duyuşsal becerilerden öz-yeterlik algıları önem kazanmaktadır (Doruk, Öztürk ve Kaplan, 2016).

Bandura (1997) sosyal öğrenme kuramında öz-yeterlik tanımını öğrenenin önceden belirlenmiş kazanım ya da çıktılara ulaşmasını sağlayacak öğrenmeleri organize etmesi ve bu öğrenmeleri gerçekleştirme potansiyeli hakkındaki yargısı olarak tanımlamışırı. Erdoğan, Baloğlu ve Kesici (2011) ise öz-yeterlik algısını öğrencinin yapabileceklerinin farkında olması ve yapabileceklerine inancı olarak tanımlamışlardır. Öz-yeterlik algısı doğuştan oluşmaz bireyin tecrübeleriyle oluşur ve zamanla gelişir (Gündoğdu, 2013). Yapılan araştırmalarda bireylerin bir işteki öz-yeterliğinin yüksek olması o işi başarmak için daha sabırlı, inatçı ve hırslı olduklarını göstermiştir (Aşkar ve Umay, 2001; Pajares,1996). Öz-yeterlik algısı matematik için önemli bir kavramdır (Kurtuluş ve Öztürk, 2017; Öztürk, 2017). Hackett ve Betz (1989) matematik özyeterlik algısını öğrenenin, matematik etkinliğini başarılı olarak yerine getirirken kendine olan güveninin değerlendirilmesi olarak tanımlar. Ural, Umay ve Argün (2008) ise matematik özyeterlik algısını bireyin bir matematik etkinliğini yapabilmesi ya da matematik problemini çözebilmesi için kendi yeteneklerine olan algıları şeklinde tanımlamışlardır. Yapılan tanımlardan yola çıkarak matematik öz-yeterlik algısı için öğrencinin matematiği başaracağına inanması, kendine güvenmesi ve matematiğe karşı olan tutumu olduğuna ulaşabiliriz. Matematik öz-yeterlik düzeyi yüksek olan öğrenciler bir matematik problemini çözerken daha fazla uğraşmakta, matematikle daha fazla zaman harcamakta, daha fazla sabır göstermekte, karar vermesi gereken durumlarda etkili yöntemler kullanabilmektedirler (Abalı Öztürk ve Şahin, 2015; Ural, 2007).

Yürekli (2008) sınıf öğretmeni adaylarının matematiğe yönelik tutumlarını ve öz-yeterlik algılarını cinsiyet, yaş, mezun oldukları lise türü, anne ve baba öğrenim durumu, öğrenim görülen üniversite değişkenlerine göre incelemiştir. Sınıf öğretmeni adaylarının öz-yeterlik algıları ve tutumları yaşa, mezun oldukları lise türüne, anne ve baba öğrenim durumuna göre istatistiksel 
olarak farklılaşmamaktadır. Cinsiyete göre sınıf öğretmeni adaylarının matematik öz-yeterlik algıları istatistiksel olarak farklılaşmakta ancak matematiğe yönelik tutumları farklılaşmamaktadır. Benzer şekilde Akay ve Boz (2011) sınıf öğretmeni adaylarının matematik öz-yeterlik algılarının ve matematiğe yönelik tutumlarının cinsiyet ve mezun oldukları lise türüne göre incelemişlerdir. Kız ve erkek sınıf öğretmeni adaylarının öz-yeterlik ve tutumları benzerdir. Matematiğe yönelik tutum mezun olunan lise türünde farklılaşırken matematik öz-yeterlik farklılaşmamaktadır. Son olarak da matematiğe yönelik tutum ve matematik öz-yeterlik arasında pozitif yönde anlamlı bir ilişki bulmuşlardır. Yavuz-Mumcu ve Aktaş-Cansız (2015) çok programlı lise öğrencilerinin matematik öz-yeterlik algılarını ve matematiğe yönelik tutumlarını cinsiyet, sınıf düzeyi, öğretim programı ve matematik başarı düzeyine göre incelemişlerdir. Öğrencilerin matematik öz-yeterlik algıları ve matematiğe yönelik tutumlarının öğretim durumu ve matematik başarı düzeyi değişkenlerine göre farklılaştığını bulmuşlardır. Cinsiyete göre tutum farklılaşmamakta fakat öz-yeterlik farklılaşmaktadır ve bu farklılık erkeklerin lehinedir. Sınıf düzeyine göre öz-yeterlik de tutum da farkl11ık göstermemektedir. Abalı Öztürk ve Şahin (2015) beşinci sınıf öğrencilerinin matematik alanındaki akademik başarı, öz-yeterlik ve tutum arasındaki ilişkileri belirlemeye çalışmışlardır. Öğrencilerin matematiğe yönelik tutumlarının cinsiyet ve matematik sınavlarının puan ortalamasına göre anlamlı farklılaşmadığını tespit etmiş̧lerdir. Matematik öz yeterliği cinsiyete göre incelediklerinde kızlar ve erkekler arasında anlamlı bir farklılık bulmuşlardır ve bu farklılık kızların lehinedir. Matematik öz-yeterlik ve matematik sınavlarının puan ortalamaları arasında da anlamlı bir fark bulmuşlardır. Doruk ve diğerleri (2016) ortaokul öğrencilerinin matematiğe yönelik tutum, matematik kaygısı ve matematik öz-yeterlik algısı arasında negatif, matematiğe yönelik tutum ile matematik öz-yeterlik algısı arasında pozitif ilişki tespit etmişlerdir. Alanyazındaki araştırmalar incelendiğinde ortaokul öğrencileriyle yapılan araştırmaların genellikle matematiğe yönelik tutumun ya da matematik özyeterliğin ayrı ayrı araştırıldığı tespit edilmiştir. Matematik öz-yeterliği ve matematiğe yönelik tutum ise çok az araştırmada birlikte incelenmiştir.

$\mathrm{Bu}$ araştırmanın amacı ortaokula devam eden öğrencilerin matematik öz-yeterlikleri ile matematik dersine yönelik tutumlarını çeşitli değişkenler bazında incelemektir. $\mathrm{Bu}$ amaç doğrultusunda araştırma problemleri "Ortaokul öğrencilerinin matematiğe yönelik tutumları ve matematik öz-yeterlikleri cinsiyete, sınıf düzeyine, okula, aylık gelire ve yazılı puanına göre farkl11ık göstermekte midir?" ve "Matematiğe yönelik tutum ve matematik öz-yeterlik arasında anlamlı bir anlamlı ilişki var mıdır?" olarak belirlenmiştir.

\section{Yöntem}

\section{Araştırma deseni}

$\mathrm{Bu}$ araştırmada ortaokul öğrencilerinin matematiğe yönelik tutumlarının ve matematik özyeterliklerinin belirlenmesi amaçlanmıştır. Araştırmanın yöntemi nicel araştırma yöntemlerinden tarama modelidir. Tarama modelinde mevcut olan bir durumun değerlendirilmesi yapılır bunun yanında kişilerin fikirlerinin düzeyini, algılarının düzeyini belirler (Ary, Jacobs, Sorensen ve Razavieh, 2010; Fraenkel, Wallen ve Hyun, 2011).

\section{Çalışma grubu}

$\mathrm{Bu}$ araştırmanın evrenini Kayseri ilindeki Melikgazi, Kocasinan ve İncesu ilçelerine devam eden ortaokul öğrencileri oluşturmaktadır. Araştırmanın örneklemini ise 2019-2020 öğretim yılının güz yarıyılında Kayseri Melikgazi ilçesindeki C Ortaokulu, Kocasinan ilçesindeki A Ortaokulu ve Kayseri ili İncesu ilçesindeki B Ortaokulu'ndaki 5, 6, 7 ve 8. sınıflarında devam eden 262 öğrenci oluşturmaktadır. 
Tablo 1.

Ortaokul Öğrencilerinin Cinsiyete, Sınıf Düzeyine, Okullara, Aylık Gelire ve Yazılı Puana Göre Dağılımı

\begin{tabular}{llll}
\hline Değişken & & $\mathrm{f}$ & $\%$ \\
\hline Cinsiyet & Kız & 111 & 42,4 \\
Sinıf düzeyi & Erkek & 151 & 57,6 \\
& 5 & 78 & 29,8 \\
& 6 & 64 & 24,4 \\
Okul adı & 7 & 68 & 26 \\
& 8 & 52 & 19,8 \\
& $\mathrm{~A}$ & 99 & 37,8 \\
Aylık gelir & $\mathrm{B}$ & 80 & 30,5 \\
& $\mathrm{C}$ & 83 & 31,7 \\
& $0-1000$ & 45 & 17,2 \\
& $1001-3000$ & 98 & 37,4 \\
& $3001-5000$ & 57 & 21,8 \\
& $5001-7000$ & 29 & 11,1 \\
Yazılı Puan1 & Toplam & 229 & 87,4 \\
& Eksik veri sayıs1 & 33 & 12,6 \\
& $0-49$ & 12 & 4,6 \\
& $50-69$ & 64 & 24,4 \\
& $70-90$ & 111 & 42,4 \\
& $91-100$ & 48 & 18,3 \\
& Toplam & 235 & 89,7 \\
& Eksik veri sayıs1 & 27 & 10,3 \\
\hline
\end{tabular}

Tablo 1'de örneklemin cinsiyete, sinıf düzeyine, okullara, aylık gelire ve yazılı puanına göre dağılımı verilmiştir. Örneklemin 111'i $(\% 42,4) \mathrm{k} 1 \mathrm{z}, 151$ 'si $(\% 56,7)$ erkek öğrencidir. Örneklemdeki $78(\% 29,8)$ öğrenci 5. sınıfa, $64(\% 24,4)$ öğrenci 6. sınıfa, 68 (\%26) öğrenci 7. sınıfa ve $52(\% 19,8)$ öğrenci 8 . sinıfa devam etmektedir. Ortaokul öğrencilerinin bulundukları okullara göre dağılımı incelendiğinde 99 öğrencinin $(\% 37,8)$ A ortaokulunda, 80 öğrencinin $(\% 30,5) \mathrm{B}$ ortaokulunda ve 83 öğrencinin $(\% 31,7) \mathrm{C}$ ortaokulunda bulunduğu görülmektedir. Ortaokul öğrencilerinin aylık gelirlerine göre dağılımı incelendiğinde 45 öğrencinin $(\% 17,2)$ aylık gelirinin 0-1000 TL aralığında olduğu, 98 öğrencinin (\%37,4) aylık gelirinin 1001-3000 TL aralığında olduğu, 57 ögrencinin $(\% 21,8)$ aylık gelirinin 3001-5000 TL aralığında olduğu, 29 öğrencinin $(\% 11,1)$ aylık gelirinin 5001-7000 TL aralığında olduğu görülmektedir. Aylık gelirini işaretlemeyen öğrenci sayısı $33(\% 12,6)$ olduğu da görülmektedir. Ortaokul öğrencilerin 20192020 yılı birinci dönem yazılı puanları incelendiğinde $12(\% 4,6)$ öğrencinin $0-49$ aralığında puan aldığ1, 64 (\%24,4) öğrencinin 50-69 aralığında puan aldığ $1,111(\% 42,4)$ öğrencinin 70-90 aralığında puan aldığı, $48(\% 18,3)$ öğrencinin 91-100 aralı̆̆ında puan aldığ 1 görülmektedir. Ayrıca $27(\% 10,3)$ öğrencinin de işaretlemediği görülmektedir.

\section{Veri toplama araçları}

$\mathrm{Bu}$ araştırmada ortaokul öğrencilerinin matematik öz-yeterlik alg1 düzeylerini belirlenmek için Umay (2001) tarafından geliştirilen "Matematik Öz-yeterlik Algısı Ölçeği”" ve matematiğe ilişkin tutumlarını belirlemek için Baykul (1990) tarafından geliştirilen "Matematik Dersine Yönelik Tutum Ölçeği” kullanılmıştır. İki ölçek de beşli Likert tipidir.

Matematik Öz-yeterlik Algısı Ölçeği: Matematik Öz-yeterlik Algısı Ölçeği, sekiz tanesi olumlu, altı tanesi olumsuz ifadelerden oluşmuştur ve toplamda 14 tane madde vardır. Alınabilecek en yüksek puan 70, en düşük puan 14'tür. Umay (2001) ölçeği matematik benlik alg1s1, matematik 
konularında davranışlarındaki farkındalık ve matematiği yaşam becerilerine dönüştürebilme olmak üzere üç alt boyutta incelemiştir. Matematik benlik algısı boyutunda 3, 10, 11, 12 ve 13. maddeler bulunmaktadır. Matematik konularındaki davranışlardaki farkındalık boyutunda 4, 5, 6, 7,8 ve 9 . maddeler bulunmaktadır. Son boyut olan matematiği yaşam becerilerine dönüştürme faktöründe 1, 2 ve 14. maddeler bulunmaktadır. Umay (2001) ölçekteki maddelerin geçerlik katsayısını 0,64 olarak bulmuştur. Bu değerin ölçeğin tümünün geçerliği konusunda bir ölçüt olarak kabul edilebileceğini ifade etmiştir. Araştırmada "Matematik Öz-yeterlik Algısı" ölçeğinin tekrar faktör analizi yapılmıştır. 14 maddelik matematik öz-yeterlik algısı ölçeğinin KaiserMeyer-Olkin (KMO) örneklem yeterlik ölçüsü 0,853>0,6'tür. KMO değeri örneklem büyüklüğünün faktör analizi yapmak için yeterli olduğunu göstermiştir. Barlett Küresellik Testi sonucuna göre örneklem homojen olarak dağılmaktadır $\left(X_{2}=888,733, s d=91, p=0,000\right)$. Tablo 6 'da matematik öz-yeterlik algısının döndürülmüş bileşen matrisleri verilmiştir. Tablo 2 incelendiğinde $1,2,4,5,8,9,13$ ve 14 . maddeler birinci boyutu $3,10,11$ ve 12 . maddeler ikinci boyutu 6 ve 7. maddeler ise üçüncü boyutu oluşturmaktadır.

Tablo 2.

Matematik Öz-yeterlik Algısı Ölçeğinin Döndürülmüş Bileşen Matrisleri

\begin{tabular}{lccc}
\hline & \multicolumn{3}{c}{ Faktörler } \\
\cline { 2 - 4 } Maddeler & 1 & 2 & 3 \\
\hline Madde_1 &, 731 &,- 192 &, 191 \\
Madde_2 &, 705 &,- 047 &, 008 \\
Madde_13 &, 689 &,- 194 &,- 118 \\
Madde_5 &, 675 &,- 234 &, 207 \\
Madde_4 &, 671 &,- 257 &, 029 \\
Madde_9 &, 644 &,- 195 &, 036 \\
Madde_14 &, 639 &,- 018 &,- 156 \\
Madde_8 &, 578 &, 058 &,- 128 \\
Madde_11 &,- 009 &, 749 &,- 093 \\
Madde_10 &,- 140 &, 655 &, 237 \\
Madde_12 &,- 177 &, 635 &, 285 \\
Madde_3 &,- 305 &, 447 &, 040 \\
Madde_6 &,- 127 &, 046 &, 823 \\
Madde_7 &, 158 &, 260 &, 702 \\
\hline
\end{tabular}

Matematiğe Yönelik Tutum Ölçeği: Matematik Dersine Yönelik Tutum Ölçeği 15'i olumlu 15'i olumsuz ifadelerden oluşmuştur ve toplamda 30 madde vardır. Maddeler 1'den 5'e kadar değişen kodlarla kodlanmıştır ve "Tamamen Katılıyorum" 5 ile, "Katılıyorum" 4 ile, "Kararsızım" 3 ile, "Katılmıyorum" 2 ile ve "Tamamen Katılmıyorum" 1 ile kodlanmıştır. Ölçekten alınabilecek en düşük puan 30 alınabilecek en yüksek puan ise 150'dir. Baykul (1990) ölçeğin Cronbach Alpha güvenirlik katsayısını 0,976 olarak bulmuştur. Ölçeğin geçerlik ve güvenirliğinin yeterli olduğunu göstermiştir.

\section{Verilerin analizi}

Ortaokul öğrencilerinden toplanan veriler SPSS 25 ile analiz edilmiştir. Faktör analizi sonucunda maddelerin dağılımı ölçeklerin orijinal dağılımıyla aynı olmadığından toplam puanlar kullanılmıştır. Araştırmanın bağımlı değişkenleri ortaokul öğrencilerinin Matematiğe Yönelik Tutum ölçeğinden ve Matematik Öz-yeterlik Algısı ölçeğinden aldıkları toplam puanlardır. Bağımsız değişkenler ise cinsiyet, sınıf, okul, aylık gelir ve yazılı puanlarıdır. Araştırmada ortaokul öğrencilerinin matematiğe yönelik tutumlarının ve matematik öz-yeterlik algılarının cinsiyete göre istatistiksel anlamda bir farklılık olup olmadığına bakmak için Mann Whitney U analizi yapılmıştır. Sınıf düzeyi, okul ve aylık gelir değişkenleri için ise Kruskal-Wallis analizleri yapılmıştır. Yazılı puanı değişkeni için öğrencilerin matematiğe yönelik tutumları normal 
dağılmadığı için Kruskal-Wallis analizi kullanılmıştır ancak matematik öz-yeterlik algısı normal dağıldığından Tek Yönlü Varyans Analizi (ANOVA) kullanılmıştır. Son olarak da matematiğe yönelik tutum ile matematik öz yeterliğin ilişkisine bakmak için Spearman Brown analizi yapılmıştır.

Bu makalede yayın etiğine uyulmuştur. Fikri hakları yazarlar dişında olan veri toplama aracı veya veri kaynağının, kullanma izni alınmıştır.

\section{Bulgular}

Bu bölümde araştırma soruları doğrultusunda toplanmış verilere yapılan analizlere ve bu analizler sonucu elde edilen bulgulara yer verilmiştir.

Matematiğe Yönelik Tutumların ve Matematik Öz-yeterliklerin Cinsiyete göre İncelenmesi Araştırmada ortaokul öğrencilerin cinsiyete göre matematiğe yönelik tutumları ve matematik özyeterlilikleri incelenmiştir. Analize başlamadan önce kız ve erkek öğrencilerin matematiğe yönelik tutumlarının ve matematik öz-yeterlik puanlarının normal dağılım gösterip göstermediği kontrol edilmiştir. Kolmogorov- Smirnov normallik analiz sonuçları Tablo 3'te verilmiştir.

Tablo 3.

Kolmogorov-Smirnov Normallik Analizi

\begin{tabular}{lllll}
\hline Ölçek & Cinsiyet & İstatistik & sd & $\mathrm{p}$ \\
\hline Tutum & Kiz &, 121 & 111 &, 000 \\
& Erkek &, 080 & 151 &, 020 \\
Öz-yeterlik & Kiz &, 103 & 111 &, 005 \\
& Erkek &, 141 & 151 &, 000 \\
\hline
\end{tabular}

Araştırmanın örneklemi 262 kişi ( $\mathrm{n} \geq 50$ ) olduğu için Kolmogorov-Smirnov normallik testi kullanılmıştır. Tablo 3 'te matematik dersine yönelik tutum ölçeğinde kız öğrencilerin $\mathrm{p}=0,000$ $<0,05$ ve erkek öğrencilerin $p=0,020<0,05$ verileri normal dağ 1 lım göstermemektedir. Matematik öz-yeterlik ölçeğinde k1z öğrencilerin $\mathrm{p}=0,005<0,05$ ve erkek öğrencilerin $\mathrm{p}=0,000<0,05$ verileri normal dağılım göstermemektedir. Kız ve erkek öğrenciler matematiğe yönelik tutum ölçeğinde ve matematik öz-yeterlik ölçeğinde normal dağılmadığı için kız ve erkek öğrencilerin matematiğe yönelik tutumlarının ve matematik öz-yeterliklerinin istatistiksel anlamda farklılaşıp farklılaşmadığına bakmak için Mann-Whitney U testi yapılmıştır. Kız ve erkek öğrencilerin matematiğe yönelik tutumlarının karşılaştırması için yapılan Mann-Whitney U testi sonucunda kız ve erkekler arasında istatistiksel olarak anlamlı bir farklılık olmadığ 1 görülmüsstür [MannWhitney $\mathrm{U}=7979 ; \mathrm{z}=-0,663 ; \mathrm{p}=0,507>0,05]$. Kız ve erkek öğrencilerin matematik özyeterliklerinin karşılaştırması için yapılan Mann-Whitney U testi sonucunda kız ve erkek öğrenciler arasında istatistiksel olarak anlamlı bir farklılık olmadığı görülmüsşür [Mann-Whitney $\mathrm{U}=7930 ; \mathrm{z}=-, 745 ; \mathrm{p}=, 457>0,05]$.

\section{Matematiğe yönelik tutumlarının ve matematik öz-yeterliklerinin sınıf düzeyinde incelenmesi}

Ortaokul öğrencilerinin matematiğe yönelik tutumlarında ve matematik öz-yeterliklerinde sınıf düzeyinde istatistiksel anlamda farklılık olup olmadığına karar vermek için öncelikle öğrencilerin matematiğe yönelik tutumlarının ve matematik öz-yeterliklerinin normal dağılımına bakılmıştır. Araştırmanın örnekleminde 5. sinıflarda 78, 6. siniflarda 64, 7. sinıflarda 68 ve 8. siniflarda 52 öğrenci $(\mathrm{n} \geq 50)$ olduğu için Kolmogorov-Smirnov normallik testi kullanılmıştır. 
Tablo 4.

Sınıf Düzeyinde Matematik Öz-yeterlik ve Matematiğe Yönelik Tutumun Kolmogorov-Smirnov Normallik Testi ve Betimsel İstatistikleri

\begin{tabular}{llllllllll}
\hline Ölçekler & $\begin{array}{l}\text { Sinıf } \\
\text { Düzeyi }\end{array}$ & İstatistik & sd & $\mathrm{p}$ & $\mathrm{n}$ & $\overline{\boldsymbol{X}}$ & $\mathrm{SS}$ & Çarpıklık & Basıklık \\
\hline Tutum & 5 &, 134 & 78 &, 001 & 78 & 91,55 & 14,530 & $-1,829$ & 9,770 \\
& 6 &, 098 & 64 &, 200 & 64 & 93,14 & 13,278 &, 222 &, 810 \\
& 7 &, 129 & 68 &, 007 & 68 & 89,10 & 12,118 & 1,305 & 4,409 \\
& 8 &, 072 & 52 &, 200 & 52 & 87,87 & 9,381 &,- 383 &, 675 \\
Öz- & 5 &, 137 & 78 &, 001 & 78 & 41,67 & 8,992 &,- 179 & 1,047 \\
yeterlik & 6 &, 120 & 64 &, 023 & 64 & 41,84 & 6,457 &,- 646 &,- 044 \\
& 7 &, 136 & 68 &, 003 & 68 & 42,63 & 7,643 & $-1,127$ & 3,178 \\
& 8 &, 109 & 52 &, 180 & 52 & 41,83 & 5,537 & $-1,058$ & 2,487 \\
\hline
\end{tabular}

Tablo 4'te altıncı sınıfa devam eden ortaokul öğrencilerinin matematiğe yönelik tutumlarının ve sekizinci sınıfa devam eden ortaokul öğrencilerinin matematiğe yönelik tutumlarının Kolmogorov-Smirnov testine göre normal dağ 1 ld 1 ğ 1 görülmektedir ( $\mathrm{p}_{6}=0,200>0,050$; $\mathrm{p} 8=0,200>0,05)$. Ancak beşinci sınıfa devam eden ortaokul öğrencilerinin matematiğe yönelik tutumları ve yedinci sınıfa devam eden ortaokul öğrencilerinin matematiğe yönelik tutumlarının Kolmogorov-Smirnov normallik testine göre normal dağılmadığ görülmüştür ( $\mathrm{p}_{5}=0,001<0,05$; $\left.\mathrm{p}_{7}=0,007<0,05\right)$. Bu yüzden Tablo 4'teki betimsel istatistiklerden beşinci sınıf öğrencilerinin ve yedinci sınıf öğrencilerinin matematiğe yönelik tutumlarının çarpıklık ve basıklık değerlerine bakılmıştır. Beşinci sınıf öğrencilerinin çarpıklık değeri $-1,829$ ve basıklık değeri ise 9,770'tir. Yedinci sınıf öğrencilerinin çarpıklık değeri 1,305 ve basıklık değeri ise 4,409'dur. Beşinci sınıf öğrencilerinin ve yedinci sınıf öğrencilerinin çarpıklık ve basıklık değerleri incelendiğinde normal dağılmadığı görülmektedir. Bu yüzden ortaokul öğrencilerinin matematiğe yönelik tutumlarının sınıf düzeyinde istatistiksel anlamda farklılık olup olmadığına bakmak için KruskalWallis testi uygulanmıştır.

Tablo 4'e bakıldığında sekizinci sınıf öğrencilerinin matematik öz-yeterliklerinin ( $\mathrm{p} 8=0,180>0,05)$ Kolmogorov-Smirnov normallik testine göre normal dağıldığı görülmektedir. Ancak 5, 6 ve 7. sinıftaki öğrencilerin matematik öz-yeterliklerinin ( $p_{5}=0,001<0,05$; $\left.\mathrm{p}_{6}=0,023<0,05 ; \mathrm{p}_{7}=0,003<0,05\right)$ Kolmogorov-Smirnov normallik testine göre normal dağılmadığ görülmektedir. Bu yüzden Tablo 4'de 5, 6 ve 7. sınıf öğrencilerinin çarpıklık ve basıklık değerlerine bakılmıştır. Beşinci sınıfların çarpıklık değeri -0,179 ve basıklık değeri ise 1,047'dir. Altıncı sınıfların çarpıklık değeri 0,646 ve basıklık değeri ise $-0,044$ 'tür. Yedinci sınıfların ise çarpıklık değeri $-1,127$ ve basıklık değeri ise 3,178 'dir. $\mathrm{Bu}$ analizler sonucu ortaokul öğrencilerinin matematik öz-yeterliklerinin sınıf düzeyinde normal dağılmadığı görülmüştür. Sınıflar arasındaki istatiksel farklılığa bakmak için Kruskal-Wallis testi yapılmıştır. KruskalWallis analizinin sonuçları incelendiğinde ortaokul öğrencilerinin matematiğe yönelik tutumlarının sınıf düzeyinde istatistiksel olarak anlamlı farklılaştığı görülmektedir [KruskalWallis $=9,814 ; \mathrm{sd}=3 ; \mathrm{p}=0,020<0,05]$. Fakat ortaokul öğrencilerinin matematik öz-yeterliklerinin sinıf düzeyinde istatistiksel anlamda farklılaşmadığı görülmektedir [Kruskal-Wallis=0,942; sd=3; $\mathrm{p}=0,812<0,05]$. Kruskal-Wallis analizi sonucunda bulunan istatistiksel anlamdaki farkl11lğın hangi sınıflar arasında olduğunu tespit etmek için Mann Whitney U analizleri yapılmıştır. Mann Whitney U analizlerinin sonuçları Tablo 5'te verilmiştir. 
Tablo 5.

Matematiğe Yönelik Tutum Puanlarının Sınıf Değişkeni için Mann Whitney U Analizi

\begin{tabular}{llll}
\hline Sinıf Düzeyi & $\mathrm{U}$ & $\mathrm{Z}$ & $\mathrm{p}$ \\
\hline 5 - 6. sinıf & 2463,5 &,- 133 &, 894 \\
5 - 7. sinıf & 2060 & $-2,325$ &, 020 \\
5 - 8. sinif & 1572 & $-2,169$ &, 030 \\
6 - 7. sinif & 1701,5 & $-2,162$ &, 031 \\
6 - 8. sinif & 1274 & $-2,167$ &, 030 \\
7 - 8. sinif & 1759 &,- 048 &, 962 \\
\hline
\end{tabular}

Tablo 5'te beşinci ve altıncı sınıf öğrencilerin matematiğe yönelik tutumlarının ortalamaları arasında istatistiksel olarak anlamlı farklılık yoktur [Mann Whitney $U=2463,5$; $z=-$ $0,133 ; p=0,894>0,05]$. Beşinci ve yedinci sınıf öğrencilerinin matematiğe yönelik tutumları arasında istatistiksel anlamda farklılık bulunmuştur [Mann Whitney $U=2060 ; z=-2,325$; $\mathrm{p}=0,02<0,05]$. Tablo 6 'da görüldüğü gibi beşinci sınıf öğrencilerinin matematiğe yönelik tutum puanlarının ortalama sırası 144,52 'dir ve yedinci sınıf öğrencilerinin ise 115,68 'dir. Bu sebeple beşinci sınıf öğrencilerinin matematiğe yönelik tutumları sekizinci sınıf öğrencilerinin matematiğe yönelik tutumlarından daha yüksektir. Beşinci ve sekizinci sınıf öğrencilerinin matematiğe yönelik tutumları arasında da istatistiksel anlamda farklılık bulunmuştur [Mann Whitney $U=1572 ; z=-2,169 ; p=0,30<0,05]$. Tablo 6 'da görüldüğ̈̈ gibi beşinci sınıf öğrencilerinin matematiğe yönelik tutum puanlarının ortalama sırası 144,52'dir ve sekizinci sınıf öğrencilerinin ise 115,4'tur. Bu sebeple beşinci sınıf öğrencilerinin matematiğe yönelik tutumları sekizinci sınıf öğrencilerinin matematiğe yönelik tutumlarından daha yüksektir. Altıncı ve yedinci sınıf öğrencilerinin matematiğe yönelik tutumları arasında istatistiksel anlamda farklılık bulunmuştur [Mann Whitney $\mathrm{U}=1701,5 ; \mathrm{z}=-2,162 ; \mathrm{p}=0,031<0,05]$. Tablo 6 'da görüldüğü gibi altınc1 sınıf öğrencilerinin matematiğe yönelik tutum puanlarının ortalamalarının sırası 145,52 ve yedinci sınıf öğrencilerinin ise $115,68^{\prime}$ tir. Altıncı sınıf öğrencilerinin matematiğe yönelik tutumları yedinci sınıf öğrencilerinin matematiğe yönelik tutumlarından yüksektir. Ancak yedinci ve sekizinci sınıf öğrencilerinin matematiğe yönelik tutumları arasında istatistiksel anlamda farklılık bulunmamaktadır [Mann Whitney $\mathrm{U}=1759 ; \mathrm{z}=0,048 ; \mathrm{p}=0,962$ ].

Tablo 6.

Kruskal-Wallis Betimsel İstatistikleri

\begin{tabular}{llll}
\hline Ölçekler & Sinıf Düzeyi & $\mathrm{n}$ & Ortalama Siras1 \\
\hline Tutum & 5 & 78 & 144,52 \\
& 6 & 64 & 145,52 \\
& 7 & 68 & 115,68 \\
Öz-yeterlik & 8 & 52 & 115,4 \\
& 5 & 78 & 129,23 \\
& 6 & 64 & 129,84 \\
& 7 & 68 & 139 \\
& 8 & 52 & 127,14 \\
\hline
\end{tabular}

Matematiğe yönelik tutumlarının ve matematik öz-yeterliklerinin okullara göre incelenmesi Ortaokul öğrencilerinin matematiğe yönelik tutumları ve matematik öz-yeterliklerini okula göre istatiksel anlamda fark olup olmadığına karar vermek için önce Kolmogorov-Smirnov normallik testi yapılmıştır. Araştırmanın örnekleminde A Ortaokulu'nda 98, B Ortaokulu'nda 81, C Ortaokulu'nda 83 öğrenci olduğundan Kolmogorov-Smirnov normallik testi kullanılmıştır. 
Tablo 7.

Okullara göre Matematik Öz-yeterlik ve Matematiğe Yönelik Tutum Betimsel ve KolmogorovSmirnov Normallik Analizi

\begin{tabular}{lllllllll}
\hline Ölçekler & Okul & $\mathrm{n}$ & $\overline{\boldsymbol{X}}$ & Çarpıklık & Basıklık & İstatistik & $\mathrm{sd}$ & $\mathrm{p}$ \\
\hline Tutum & $\mathrm{A}$ & 98 & 91,20 &,- 905 & 8,687 &, 138 & 98 &, 000 \\
& $\mathrm{~B}$ & 81 & 89,94 &, 100 &,- 057 &, 079 & 81 &, 462 \\
& $\mathrm{C}$ & 83 & 87,60 &,- 358 &, 614 &, 079 & 83 &, 150 \\
Öz- & $\mathrm{A}$ & 98 & 41,83 &,- 221 & 2,287 &, 133 & 98 &, 007 \\
yeterlik & $\mathrm{B}$ & 81 & 41,64 &,- 719 &, 392 &, 131 & 81 &, 007 \\
& $\mathrm{C}$ & 83 & 41,39 &,- 981 & 2,119 &, 107 & 83 &, 001 \\
\hline
\end{tabular}

Tablo 7'ye göre A Ortaokulu'ndaki öğrencilerin matematiğe yönelik tutumlarının $(\mathrm{p}=0,000<0,05)$ normal dağ 1 lmadığ 1 görülmektedir. Bu yüzden Tablo 7'de verilen çarpıklık basıklık değerlerine bakılmıştır. A Ortaokulu'ndaki öğrencilerin matematiğe yönelik tutumlarının çarpıklık değeri $-0,905$ ve basıklık değeri ise $8,868^{\prime}$ 'dir. B Ortaokulu'ndaki öğrencilerin matematiğe yönelik tutumlarının $(p=0,462>0,05)$ ve $C$ Ortaokulu'ndaki öğrencilerin matematiğe yönelik tutumlarının $(\mathrm{p}=0,150>0,05)$ Kolmogorov-Smirnov testine göre normal dağıldığ 1 görülmektedir. Tablo 7'ye göre A Ortaokulu'ndaki öğrencilerin matematik öz-yeterliklerinin $(\mathrm{p}=0,007<0,05)$, B Ortaokulu'ndaki öğrencilerin matematik öz-yeterliklerinin $(\mathrm{p}=0,007<0,05)$ ve C Ortaokulu'ndaki öğrencilerin matematik öz-yeterliklerinin $(0,001<0,05)$ normal dağılmadığ görülmektedir. Bu yüzden Tablo 7'de verilen çarpıklık ve basıklık değerlerine bakılmıştır. A Ortaokulu'ndaki öğrencilerin matematik öz-yeterliklerinin çarpıklık değeri $-0,221$ ve basıklık değeri ise 2,287' dir. B Ortaokulu'ndaki öğrencilerin matematik öz-yeterliklerinin çarpıklık değeri $-0,719$ ve basıklık değeri ise 0,392 'dir. C Ortaokulu'ndaki öğrencilerin matematik özyeterliklerinin çarpıklık değeri $-0,981$ ve basıklık değeri ise 2,119'tur. Analiz sonuçlarına göre ortaokul öğrencilerinin okullara göre normal dağılmadığı görülmüştür. Kruskal-Wallis analiz sonuçlarına göre ortaokul öğrencilerinin matematiğe yönelik tutumlarının okullara göre istatistiksel olarak anlamlı farklılaştı̆g görülmektedir [Kruskal-Wallis= 7,836; $\mathrm{sd}=2 ; \mathrm{p}=$ $0,02<0,05]$. Fakat ortaokul öğrencilerinin matematik öz-yeterliklerinin okullara göre istatistiksel anlamda farklılaşmadığı görülmektedir [Kruskal-Wallis=0,383; $\mathrm{sd}=2 ; \mathrm{p}=0,826<0,05$ ]. KruskalWallis analizi sonucunda bulunan istatistiksel anlamdaki farklılığın hangi sınıflar arasında olduğunu tespit etmek için Mann Whitney U analizleri yapılmıştır. Mann Whitney U analizlerinin sonuçları Tablo 8'de verilmiştir.

Tablo 8.

Matematiğe Yönelik Tutum Puanlarının Okul Değişkeni için Mann Whitney U Analizleri

\begin{tabular}{llll}
\hline Okul & $\mathrm{U}$ & $\mathrm{Z}$ & $\mathrm{p}$ \\
\hline A- B & 3818,5 &,- 436 &, 663 \\
A- C & 3235,5 &,- 370 &, 018 \\
B- C & 2610,5 & $-2,472$ & 0,13 \\
\hline
\end{tabular}

Tablo 8'de A ve B Ortaokulu'nda okuyan öğrencilerin matematiğe yönelik tutumları arasında istatistiksel olarak anlamlı bir farklılık bulunmamaktadır [Mann Whitney $\mathrm{U}=3818,5$; $\mathrm{z}=-0,436 ; \mathrm{p}=0,663>0,05]$. A Ortaokulu'nda okuyan öğrencilerin ve C Ortaokulu'nda okuyan öğrencilerin matematiğe yönelik tutumları arasında istatistiksel anlamda farklılık bulunmuştur [Mann Whitney $U=3235,5 ; \mathrm{z}=-0,37 ; \mathrm{p}=0,018<0,05]$. Tablo 9'da görüldüğ gi gibi A Ortaokulu'nda okuyan öğrencilerin matematiğe yönelik tutum puanlarının ortalama sırası $138,45^{\prime}$ tir ve C Ortaokulu'nda okuyan öğrencilerin ise 112,43'tür. A Ortaokulu'nda okuyan öğrencilerin matematiğe yönelik tutumları C Ortaokulu'nda okuyan öğrencilerin matematiğe yönelik tutumlarından daha yüksektir. B Ortaokulu'nda okuyan öğrencilerin ve C Ortaokulu'nda okuyan öğrencilerin matematiğe yönelik tutumları arasında istatistiksel anlamda bir farklılık bulunmuştur [Mann Whitney $\mathrm{U}=2610,5 ; \mathrm{z}=-2,472 ; \mathrm{p}=0,13<0,05]$. B Ortaokulu'nda okuyan öğrencilerin 
matematiğe yönelik tutum puanlarının ortalama sırası 142,63'tür ve C Ortaokulu'nda okuyan öğrencilerin ise 112,43 'tür. B Ortaokulu'nda okuyan öğrencilerin matematiğe yönelik tutumları C Ortaokulu'nda okuyan öğrencilerin matematiğe yönelik tutumlarından daha yüksektir.

Tablo 9.

Kruskal-Wallis Betimsel İstatistikleri

\begin{tabular}{llll}
\hline Ölçekler & Okul & $\mathrm{n}$ & Ortalama Siralamas1 \\
\hline Tutum & $\mathrm{A}$ & 98 & 138,45 \\
& $\mathrm{~B}$ & 81 & 142,63 \\
Öz-yeterlik & $\mathrm{C}$ & 83 & 112,43 \\
& $\mathrm{~A}$ & 98 & 128,21 \\
& $\mathrm{~B}$ & 81 & 131,70 \\
& $\mathrm{C}$ & 83 & 135,19 \\
\hline
\end{tabular}

Matematik öz-yeterliklerinin ve matematiğe yönelik tutumlarının aylık gelir düzeyinde incelenmesi

Ortaokula devam eden öğrencilerin matematiğe yönelik tutumlarının ve matematik özyeterliklerinin aylık gelir düzeyine göre istatiksel anlamda farklılaşıp farklılaşmadığına karar vermek için öncelikle normallik testi yapılmıştır. Araştırmanın örnekleminde 0-1000 TL arasında aylık geliri olan 45 öğrenci ve 5001-7000TL arasındaki aylık geliri olan 29 öğrenci $(n<50)$ olduğundan Shapiro-Wilk normallik testi yapılmıştır. 1001-3000 TL arasında aylık geliri olan 98 öğrenci ve 3001-5000 TL arasında aylık geliri olan 57 öğrenci ( $>50)$ olduğundan KolmogorovSmirnov Testi uygulanmıştır.

Tablo 10.

Aylık Gelirlerine göre Matematiğe Yönelik Tutum ve Matematik Öz Yeterliğin Shapiro-Wilk ve Kolmogorov-Smirnov Normallik Testi

\begin{tabular}{llllllll}
\hline & & \multicolumn{3}{l}{ Shapiro-Wilk } & \multicolumn{5}{c}{ Kolmogorov-Smirnov } \\
Ölçekler & Aylı Gelir & İstatistik & $\mathrm{sd}$ & $\mathrm{p}$ & İstatistik & $\mathrm{sd}$ & $\mathrm{p}$ \\
Tutum & $0-1000$ &, 972 & 45 &, 333 & & & \\
& $1001-3000$ & & & &, 112 & 98 &, 004 \\
& $3001-5000$ & & & &, 108 & 57 &, 98 \\
\multirow{3}{*}{ Öz-yeterlik } & $5001-7000$ &, 796 & 29 &, 000 & & & \\
& $0-1000$ &, 937 & 45 &, 017 & & & \\
& $1001-3000$ & & & &, 121 & 98 &, 001 \\
& $3001-5000$ & & & &, 156 & 57 &, 001 \\
& $5001-7000$ &, 859 & 29 &, 001 & & & \\
\hline
\end{tabular}

Tablo 10'a göre Shapiro-Wilk normallik testi sonucunda 0-1000 TL arasındaki öğrencilerin matematiğe yönelik tutumları $(p=0,333>0,05)$ olduğundan normal dağılım göstermektedir. Fakat 5001-7000 TL arasındaki öğrencilerin matematiğe yönelik tutumları $(\mathrm{p}=0,000<0,05)$ olduğundan normal dağılım göstermemektedir. $\mathrm{Bu}$ yüzden 5001-7000 TL arasındaki öğrencilerin matematiğe yönelik tutumlarının çarpıklık ve basıklık değerlerine bakılmıştır. Çarpıklık değeri 2,285 ve basıklık değeri ise 8,324'tür. Kolmogorov-Smirnov normallik testi sonucunda 1001-3000 TL arasındaki öğrencilerin matematiğe yönelik tutumları $(\mathrm{p}=0,004<0,05)$ normal dağılım göstermemektedir. Bu yüzden 1001-3000 TL arasındaki öğrencilerin çarpıklık değeri -1,852 ve basıklık değeri ise 10,637'dir. 3001-5000 TL arasındaki öğrencilerin matematiğe yönelik tutumları $(\mathrm{p}=0,098>0,05)$ normal dağılım göstermektedir. Shapiro-Wilk normallik testi sonucunda 0-1000 TL arasında öğrencilerin matematik özyeterlikleri $(\mathrm{p}=0,017<0,05)$ ve 5001-7000 TL arasındaki öğrencilerin matematik öz-yeterlikleri $(\mathrm{p}=0,001<0,05)$ normal dağ $11 \mathrm{~lm}$ göstermemektedir. Bu yüzden 0-1000 TL arasındaki öğrencilerin ve 5001-7000 TL arasındaki öğrencilerin çarpıklık ve basıklık değerlerine bakılmıştır. 0-1000 TL 
arasındaki öğrencilerin çarpıklık değeri -0,281 ve basıklık değeri ise 1,200'dür. 5001-7000 TL arasındaki öğrencilerin çarpıklık değeri $-1,613$ ve basıklık değeri ise 5,133'tür. Tablo 10 'a göre 1001-3000 TL arasındaki öğrencilerin matematik öz-yeterlikleri $(\mathrm{p}=0,001<0,05)$ ve 3001-5000 TL arasındaki öğrencilerin matematik öz-yeterlikleri $(\mathrm{p}=0,001<0,05)$ olduğundan normal dağılmamaktadırlar. 1001-3000 TL arasındaki öğrencilerin çarpıklık değeri $-0,629$ ve basıklık değeri ise 0,508 'dir. 3001-5000 TL arasındaki öğrencilerin çarpıklık değeri -,0575 ve basıklık değeri ise 1,063'tür. Shapiro-Wilk ve Kolmogorov-Smirnov analizleri sonucunda ortaokul öğrencilerinin matematiğe yönelik tutumları ve matematik öz-yeterlikleri aylık gelire göre normal dağ $11 ı$ göstermemektedir. Bu yüzden ortaokul öğrencilerinin matematiğe yönelik tutumlarının ve matematik öz-yeterliklerinin aylık gelire göre farklılaşıp farklılaşmadığına bakmak için Kruskal-Wallis analizi yapılmıştır. Kruskal-Wallis analizinin sonuçlarına göre ortaokul öğrencilerinin matematiğe yönelik tutum puanları aylık gelire göre istatistiksel anlamda anlamlı farklılık göstermektedir [Kruskal-Wallis $=8,287 ; \mathrm{sd}=3 ; \mathrm{p}=0,040<0,05$ ]. Aylık gelirleri farklı olan ortaokul öğrencilerinin matematik öz-yeterlik puanları arasında istatistiksel anlamda farklılık bulunmamıştır [Kruskal- Wallis $=8,287 ; \mathrm{sd}=3 ; \mathrm{p}=0,184>0,05$ ]. Kruskal-Wallis analizi sonucunda istatistiksel anlamda farklılık bulunan ortaokul ögrencilerinin tutumlarının hangi aylık gelire göre farklılaştığını bulmak için Mann Whitney U analizleri yapılmıştır. Tablo 11'de Mann Whitney $\mathrm{U}$ betimsel analizlerinin sonuçları verilmiştir.

Tablo 11.

Kruskal-Wallis Betimsel İstatistikleri

\begin{tabular}{llll}
\hline Ölçekler & Aylik Gelir & $\mathrm{n}$ & Ortalama Siras1 \\
\hline Tutum & $0-1000 \mathrm{TL}$ & 45 & 128 \\
& $1001-3000 \mathrm{TL}$ & 98 & 123,07 \\
& $3001-5000 \mathrm{TL}$ & 57 & 97,63 \\
& 5001-7000TL & 29 & 101,69 \\
Öz-yeterlik & $0-1000 \mathrm{TL}$ & 45 & 106,96 \\
& $1001-3000 \mathrm{TL}$ & 98 & 117,96 \\
& 3001-5000TL & 57 & 105,71 \\
& 5001-7000TL & 29 & 135,72 \\
\hline
\end{tabular}

Tablo 12

Matematiğe Yönelik Tutum ve Matematik Öz-yeterlik Puanlarının Aylık Gelir için Mann Whitney U Analizi

\begin{tabular}{llll}
\hline Ayl1k Gelir & $\mathrm{U}$ & $\mathrm{z}$ & $\mathrm{p}$ \\
\hline 0-100TL- 1001-3001TL & 2064,5 & $-0,611$ & 0,541 \\
0-1000TL- 3001-5000TL & 967 & $-2,128$ & 0,033 \\
0-1000TL- 5001-7000TL & 523,5 & $-1,43$ & 0,153 \\
1001-3000TL- 3001-5000TL & 2140,5 & $-2,423$ & 0,015 \\
1001-3000TL- 5001-7000TL & 1142 & $-1,604$ & 0,109 \\
3001-5000TL- 5001-7000TL & 804,5 & $-0,201$ & 0,840 \\
\hline
\end{tabular}

Tablo 12'ye göre Mann Whitney U testleri sonucunda aylık geliri 0-1000 TL arasında olan öğrenciler ile aylık geliri 1001-3000 TL arasında olan öğrencilerin matematiğe yönelik tutumları arasında istatistiksel anlamda fark bulunmamıştır [Mann Whitney $\mathrm{U}=2064,5 ; \mathrm{z}=$ $0,611 ; p=0,541>0,05]$. Aylık geliri 0-1000 TL arasında olan öğrenciler ile aylık geliri 3001$5000 \mathrm{TL}$ arasındaki ögrencilerin ise aralarında anlamlı farklılık vardır [Mann Whitney $U=967$; $\mathrm{z}=-2,128 ; \mathrm{p}=0,033<0,05] .0-1000 \mathrm{TL}$ arasında aylık geliri olan öğrencilerin matematiğe yönelik ortalamalarının sırası 128'dir. 3001-5000 TL arasında aylık geliri olan öğrencilerin matematiğe yönelik tutumlarının ortalama sıralaması 97,63'tür. Bu sebeple 0-1000 TL arasında aylık geliri olan öğrencilerin matematiğe yönelik tutumları 3001-5000 TL arasında aylık geliri olan öğrencilerin matematiğe yönelik tutumları yüksektir. Aylık geliri 0-1000 TL arasında olan 
öğrenciler ile 5001- $7000 \mathrm{TL}$ arasında olan öğrencileri matematiğe yönelik tutumları arasında istatistiksel anlamda bir farklılık bulunmamaktadır [Mann Whitney $\mathrm{U}=523,5 ; \mathrm{z}=-1,43 ; \mathrm{p}=$ $0,153>0,05]$. Aylık geliri 1001-3000TL arasında olan öğrenciler ile 3001- 5000TL arasında olan öğrencileri matematiğe yönelik tutumları arasında istatistiksel anlamda farklılık vardır [Mann Whitney $\mathrm{U}=2140,5 ; \mathrm{z}=-2,423 ; \mathrm{p}=0,015<0,05]$. 1001-3000 TL arasinda aylik geliri olan öğrencilerin ortalama sirası 117,962'dir ve 3001-5000 TL aylık geliri olan öğrencilerin ortalama sıras1 105,71'dir. Bu sebeple aylık geliri 1001-3000 TL arasında olan öğrencilerin matematiğe yönelik tutumları 3001-5000 TL arasında aylık geliri olan öğrencilerin matematiğe yönelik tutumlarından yüksektir. Aylık geliri 1001-3000 TL arasında olan öğrenciler ile 5001-7000 TL arasında olan öğrencilerin matematiğe yönelik tutumları arasında istatistiksel anlamda bir farklılık yoktur [Mann Whitney $U=1142 ; z=-1,604 ; p=0,109>0,05$ ]. Son olarak aylık geliri 3001-5000 TL arasında olan öğrenciler ile 5001- 7000 TL arasında olan öğrencileri matematiğe yönelik tutumları arasında istatistiksel anlamda farklılık yoktur [Mann Whitney $U=804,5 ; z=-0,201 ; p=$ $0,840>0,05]$.

\section{Matematiğe yönelik tutumlarının yazılı puanına göre incelenmesi}

Ortaokul öğrencilerinin matematiğe yönelik tutumlarının yazılı puanına göre istatiksel anlamda farklılaşıp farklılaşmadığına karar vermek için öncelikle normallik testi yapılmıştır. Araştırmanın örnekleminde 0-49 puan aralığında olan 12 öğrenci, 91-100 puan aralığında olan 48 öğrenci $(\mathrm{n}<50)$ olduğundan Shapiro-Wilk normallik testi yapılmıştır. 50-68 puan aralığında olan 64 öğrenci ve 70-90 puan aralığında olan 111 öğrenci $(n>50)$ olduğundan Kolmogorov-Smirnov analizi yapılmışırır.

Tablo 13.

Yazılı Puanına göre Matematiğe Yönelik Tutumun Betimsel İstatistik ve Shapiro-Wilk ve Kolmogorov-Smirnov Normallik Analizi

\begin{tabular}{llllllllllll}
\hline & Yazılı & & & \multicolumn{1}{c}{ Shapiro-Wilk } & \multicolumn{4}{c}{ Kolmogorov-Smirnov } \\
Ölçek & Puanı & $\mathrm{n}$ & $\overline{\boldsymbol{X}}$ & Çarpıklık & Basılk1k & İstatistik & $\mathrm{sd}$ & $\mathrm{p}$ & İstatistik & $\mathrm{sd}$ & $\mathrm{p}$ \\
\hline \multirow{4}{*}{ Tutum } & $0-49$ & 12 & 90,5 &, 606 &,- 495 &, 945 & 12 &, 571 & & & \\
& $50-69$ & 64 & 89,92 & $-1,06$ & 9,231 & & & &, 157 & 64 &, 000 \\
& $70-90$ & 111 & 89,99 &, 003 &, 432 & & & &, 078 & 111 &, 097 \\
& $91-$ & & & & & & & & & & \\
& 100 & 48 & 89,85 &, 094 & 1,289 &, 956 & 48 &, 068 & & & \\
\hline
\end{tabular}

Tablo 13'e göre matematiğe yönelik tutum ölçeğinde 0-49 puan aralığında olan öğrencilerin $(p=0,571>0,05)$ ve 91-100 puan aralığında olan öğrencilerin $(p=0,068>0,05)$ Shapiro-Wilk normallik testine göre normal dağıldığ 1 görülmektedir. 70-90 puan aralığında olan öğrencilerin matematiğe yönelik tutumları $(\mathrm{p}=0,97>0,05)$ Kolmogorov-Smirnov normallik testine göre normal dağıldığı görülmektedir. 50-69 puan aralığında olan öğrencilerin matematiğe yönelik tutumları $(\mathrm{p}=0,000<0,05)$ Kolmogorov-Smirnov normallik testine göre normal dağılmamıştır. $\mathrm{Bu}$ yüzden çarpıklık ve basıklık değerlerine bakılmıştır. Tablo 13'te görüldü̆g̈ü gibi 50-69 puan aralığında olan öğrencilerin matematik tutumlarının çarpıklık değeri -1,060'tır. Basıklık değeri ise 9,231'dir. Yani 50-69 puan aralığında olan öğrencilerin matematiğe yönelik tutumları normal dağılmamaktadır. Yapılan Kolmogorov-Smirnov normallik analizi sonucu 50-69 puan aralığında olan öğrencilerinin matematiğe yönelik tutumları normal dağılmadığı ve basıklık değeri $(9,231)$ yüksek olduğundan ortaokul öğrencilerinin matematiğe yönelik tutumlarının yazılı puanına göre istatistiksel anlamda farklılaşıp farklılaşmadığını incelemek için Kruskal-Wallis analizi yapılmıştır. Kruskal-Wallis analizinde ortaokul öğrencilerinin matematiğe yönelik tutumlarının yazılı puanına göre istatistiksel anlamda farklı1ık olmadığı bulunmuştur [Kruskal-Wallis $=0,146$; $\mathrm{sd}=3 ; \mathrm{p}=0986>0,05]$. 


\section{Matematik öz-yeterliklerinin yazılı puanı düzeyine göre incelenmesi}

Ortaokul öğrencilerinin matematik öz-yeterliklerinin yazılı puanı düzeyine göre istatiksel anlamda farklılaşıp farklılaşmadığına karar vermek için öncelikle normallik testi yapılmıştır. Araştırmanın örnekleminde 0-49 puan aralığında olan 12 öğrenci, 91-100 puan aralığında olan 48 öğrenci $(\mathrm{n}<50)$ olduğundan Shapiro-Wilk normallik testi yapılmıştır. 50-68 puan aralığında olan 64 öğrenci ve 70-90 puan aralığında olan 111 öğrenci (n>50) olduğundan Kolmogorov-Smirnov analizi yapılmıştır. Betimsel istatistik değerleri ve Kolmogorov-Smirnov ve Shapiro-Wilk normallik analizi Tablo 14'te verilmiştir.

Tablo 14.

Yazılı Puanına göre Matematik Öz Yeterliğin Betimsel İstatistik Kolmogorov-Smirnov ve Shapiro-Wilk Normallik Analizi ve Betimsel Analizi

\begin{tabular}{|c|c|c|c|c|c|c|c|c|c|c|c|}
\hline & Yazilı & & & & & Kolmogo & ov-Si & irnov & Shapiro- & Tilk & \\
\hline Ölçek & Puanı & $\mathrm{n}$ & $\bar{X}$ & Çarpıklık & Basıklık & İstatistik & sd & $\mathrm{p}$ & İstatistik & $\mathrm{sd}$ & $\mathrm{p}$ \\
\hline \multirow{4}{*}{$\begin{array}{l}\text { Öz- } \\
\text { yeterlik }\end{array}$} & $0-49$ & 12 & 41,92 & , 194 & $-1,019$ & \multirow{4}{*}{$\begin{array}{l}, 155 \\
, 136\end{array}$} & \multirow{4}{*}{$\begin{array}{l}64 \\
111\end{array}$} & \multirow{4}{*}{$\begin{array}{l}, 001 \\
, 000\end{array}$} & 959 & 12 & ,763 \\
\hline & $50-69$ & 64 & 41,03 &,- 422 & 1,79 & & & & & & \\
\hline & 70-90 & 111 & 42,24 &,- 685 & 1,335 & & & & & & \\
\hline & 100 & 48 & 43,44 &,- 016 & ,001 & & & & ,965 & 48 & , 168 \\
\hline
\end{tabular}

Tablo 14'e göre 50-69 puan aralığında $(\mathrm{p}=0,001<0,05)$ ve $70-90$ puan aralığında $(\mathrm{p}=0,000<0,05) \quad$ olan öğrencilerin matematik öz-yeterliklerinin normal dağılmadiğ 1 görülmektedir. Bu yüzden 50-69 puan aralığındakilerin ve 70-90 puan aralığındakilerin çarpıklık ve basıklık değerlerine bakılmıştır. Tablo 14'e göre 50-69 puan aralığında olan öğrencilerin matematik öz-yeterliklerinin çarpıklık değeri $-0,422$ ve basıklık değeri ise 1,790'dır. 70-90 puan aralığında olan öğrencilerin matematik öz-yeterliklerinin çarpıklık değeri $-0,685$ ve basıklık değeri ise 1,335'tir. Çarpıklık ve basıklık değerleri-2 ile 2 değer aralığında olduğundan normal dağılım şartını sağlamaktadırlar. 0-49 puan aralığında olan öğrencilerin matematik öz-yeterlikleri $(\mathrm{p}=0,763>0,05)$ ve 91-100 puan aralı̆̆ında olan öğrencilerin matematik öz-yeterlikleri $(\mathrm{p}=0,168>0,05)$ normal dağılım sağlamaktadırlar.

Ortaokul öğrencilerinin matematik öz-yeterliklerinin yazılı puanı düzeyine göre farklılaşıp farklılaşmadığına bakmak için Tek Yönlü ANOVA analizi yapılmıştır. Bu analizi yapmadan önce Levene Homojenlik testiyle öğrencilerin matematik öz-yeterliklerinin homojenliğine bakılmıştır. Levene Homojenlik testinin analiz sonuçlarına göre ortaokul öğrencilerinin matematik öz-yeterlikleri homojen dağılmamaktadır $[F(4,257)=2,437$; $\mathrm{p}=0,048<0,05]$. Bu yüzden matematik öz yeterliğin homojenliği için Welch ve Brown Forsythe testleri incelenmiștir. Tablo 15 incelendiğinde ortaokul öğrencilerinin matematiğe yönelik tutumlarının Welch $(\mathrm{p}=0,285>0,05)$ ve Brown-Forsythe testine $(\mathrm{p}=0,379>0,05)$ göre homojen dağıldı ğı görülmektedir.

Tablo 15.

Matematik Öz-yeterlik Puanlarının Yazılı Puanı Düzeyi Değişkeni için Welch ve Brown-Forsythe Homojenlik Testi Analizi

\begin{tabular}{lllll}
\hline Test & İstatistik & $\mathrm{sd} 1$ & $\mathrm{sd} 2$ & $\mathrm{p}$ \\
\hline Welch & 1,288 & 4 & 58,054 &, 285 \\
Brown-Forsythe & 1,060 & 4 & 131,839 &, 379 \\
\hline
\end{tabular}




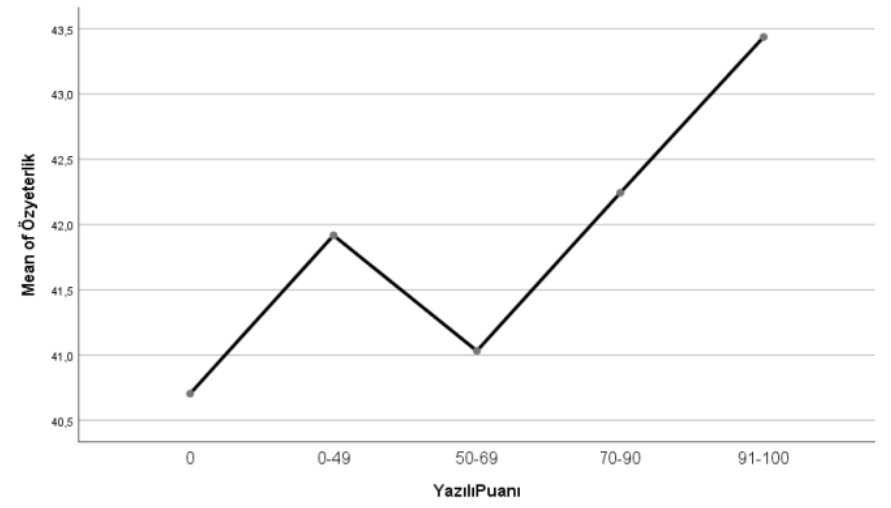

Şekil 1. Öğrencilerin Yazılı Puanlarına Göre Matematik Öz-yeterlik Ortalama Grafiği

Şekil 1'e göre 0-49 puan aralığında olan öğrencilerin ortalamaları 41,92; 50-69 puan aralığında olan öğrencilerin ortalamaları 41,03; 70-90 puan aralığında olan öğrencilerin ortalamaları 42,24 ve 91-100 puan aralığında olan öğrencilerin ortalamaları 43,44'tür. Öğrencilerin yazılı puanları değiştikçe matematik öz-yeterlik ortalamaları matematiksel anlamda değişmektedir. Fakat ortaokul öğrencilerinin yazılı puanları ve matematik öz-yeterlikleri arasında istatistiksel anlamda farkl1lik yoktur $[\mathrm{F}(4,257)=0,959 ; \mathrm{p}=0,431>0,05]$.

\section{Matematik öz-yeterlik ile matematiğe yönelik tutumun ilişkisi}

Ortaokul ögrencilerinin matematiğe yönelik tutumları ile matematik öz-yeterlikleri arasındaki ilişkiyi analiz edebilmek için öncelikle normal dağılıma bakılmıştır. Araştırmanın örneklemini 262 öğrenci oluşturduğu için Kolmogorov-Smirnov normallik analizi yapılmıştır ve Tablo 16' da verilmiştir.

Tablo16.

Matematiğe Yönelik Tutum ve Matematik Öz Yeterliğin Kolmogorov-Smirnov Analizi

\begin{tabular}{llll}
\hline Ölçekler & İstatistik & sd & $\mathrm{p}$ \\
\hline Tutum &, 085 & 262 &, 000 \\
Öz-yeterlik &, 126 & 262 &, 000 \\
\hline
\end{tabular}

Tablo 16'da matematiğe yönelik tutum $(\mathrm{p}=0,000<0,05)$ ve matematik öz-yeterlik $(\mathrm{p}=0,000<0,05)$ ölçekleri normal dağ 11 lı göstermemektedir. Bu yüzden öğrencilerin matematiğe yönelik tutumları ve matematik öz-yeterlikleri arasında anlamlı bir ilişki olup olmadığını belirlemek için yapılan Spearman korelasyon analizi sonuçları incelendiğinde, öğrencilerin matematik öz-yeterlikleri ile matematiğe yönelik tutumları arasında ilişkinin olmadığ görülmektedir $[\mathrm{r}=-0,062 ; \mathrm{p}=0,302]$.

\section{Tartıșma}

Bu bölümde araştırma sonucunda elde edilen bulgular alanyazındaki araştırmalarla tartışılmıştır. Araştırmada ortaokul öğrencilerinin matematiğe yönelik tutumlarının düzeyi ve matematik özyeterlik algıları cinsiyet, sınıf, okul, aylık gelir ve yazılı puanına göre incelenmiştir.

$\mathrm{Bu}$ araştırmada ortaokul öğrencilerinin matematiğe yönelik tutumlarının cinsiyete göre farklılaşmadığı sonucuna ulaşıımıştır. Alanyazında matematiğe yönelik tutumun cinsiyete göre farklılaşmadığı sonucuna ulaşan araştırmalar vardır (Çavdar, 2019; Birgin ve Demirkan, 2017; Karaduman, 2018; Koca, 2011; Sevgi ve Orman, 2020; Tuncer ve Y1lmaz, 2016). K1z ve erkek öğrencilerin matematiğe yönelik tutumlarının birbirine benzer olduğu sonucunu destekler niteliktedir. Bu araştırmaların aksine ortaokul öğrencilerinin matematiğe yönelik tutumlarının cinsiyete göre farklılaştığı sonucuna ulaşan araştırmalar da vardır. Farklılı̆̆ın kızların lehine 
olduğu yani kızların matematiğe yönelik tutumlarının erkeklerin matematiğe yönelik tutumlarından yüksek olduğu sonucuna ulaşılmıştır (Çelik ve Bindak, 2005; Katrancı ve Şengül, 2019). Diğer taraftan, Pehlivan (2012) ortaokul öğrencileriyle yaptığı araştırmasından erkeklerin matematiğe yönelik tutumlarının kızların matematiğe yönelik tutumlarından yüksek olduğu sonucuna ulaşmıştır. Matematiğe yönelik tutumlara göre öğretim tasarlanırken kız ve erkek öğrenciler arasında farklılık olmadan tasarlanabilir.

Ortaokul öğrencilerinin matematik öz-yeterlik algılarının cinsiyete göre anlamlı farklılaşmadığı sonucuna ulaşılmıştır. Araştırmaya katılan kız ve erkek öğrencilerin matematik öz-yeterlik algılarının benzer olduğunu söylenebilir. Alanyazında matematik öz-yeterlik algısının cinsiyete göre farklılaşmadığ 1 sonucuna ulaşan araştırmalar vardır (Akay ve Boz, 2011; Goodwin, Ostrom ve Scott, 2009; Öztürk ve Kurtuluş, 2017; Öztürk, 2017; Takır, 2018). Bu araştırmaların aksine matematik öz-yeterlik algısının cinsiyete göre anlamlı olarak farklılaştığı sonucuna ulaşan araştırmalar da bulunmaktadır (Adal ve Yavuz, 2017; Oğuz ve Kutlu-Kalender, 2018; Rençber, 2011). Ortaokul öğrencileriyle yapılan araştırmalarda kız ve erkek öğrencilerin matematik özyeterlik algıları arasında anlamlı bir fark bulunmuştur ve bu fark erkek öğrencilerin lehinedir (Adal ve Yavuz, 2017; Rençber, 2011). Oğuz ve Kutlu-Kalender (2018) ortaokul öğrencileriyle yaptıkları araştırmada kız ve erkek öğrencilerin matematik öz-yeterlikleri arasında farklılık olduğu sonucuna ulaşmıştır ve kız öğrencilerin matematik öz-yeterlik algıları erkeklerden yüksektir. Alanyazındaki araştırmaların birbirinden farklı olmasının sebebi araştırmaların örneklemlerinin farklı olması, araştırmaya katılan kişilerin hazır bulunurluk düzeylerinin farklı olması veya kullanılan ölçeklerin farklı olması olabilir. Bu araştırmanın bulguları doğrultusunda ortaokula devam eden kı ve erkek öğrencilerinin öz-yeterlik seviyeleri farklılık göstermediğinden öğretim tasarımlarında kızların ve erkeklerin öz-yeterliklerine aynı seviyede hitap eden tasarımlar önerilebilir.

Ortaokul öğrencilerinin matematiğe yönelik tutumları sınıf değişkenine göre incelenmiştir ve sınıflar arasında istatistiksel anlamda farklılık bulunmuştur. Matematiğe yönelik tutumda bulunan farklılık beşinci ile yedinci sınıf arasında, beşinci ile sekizinci sınıf arasında ve altıncı ile yedinci sınıf arasındadır. Beşinci sınıf öğrencilerinin matematiğe yönelik tutumu yedinci sınıf öğrencilerinin matematiğe yönelik tutumundan yüksektir. Aynı şekilde beşinci sınıf öğrencilerinin matematiğe yönelik tutumları sekizinci sınıf öğrencilerinin matematiğe yönelik tutumundan da yüksektir. Son olarak altıncı sınıf öğrencilerinin matematiğe yönelik tutumları yedinci sınıf öğrencilerinin matematiğe yönelik tutumundan yüksektir. Ancak matematiğe yönelik tutum beşinci ile altıncı sınıf arasında ve yedinci ile sekizinci sınıf arasında farklılaşmamaktadır. Elde edilen sonuçlara göre matematiğe yönelik tutum sınıf düzeyi arttıkça düşmektedir. Bu sonucu destekleyen araştırmalar bulunmaktadır (Çıtdır, 2019; Gülburnu ve Yıldırım, 2015; Katrancı ve Şengül, 2019; Tan, 2015; Taşdemir, 2009). Alanyazındaki araştırmalar incelendiğinde sınıf düzeyi arttıkça matematiğe yönelik tutumun azaldığı konusunda benzerlik göstermektedir.

Ortaokul öğrencilerinin matematik öz-yeterlik algılılarının sınıf düzeyine göre incelendiğinde sınıflar arasında istatistiksel olarak anlamlı bir farklılık bulunmamıştır. Sınıf düzeyi arttıkça öz-yeterliğin değişmediği gözlemlenmiştir. Alanyazında bu sonucu destekleyen araştırmalar bulunmaktadır. Uzar (2010) 6, 7 ve 8. sinıflarla yaptığı araştırmasında 6,7 ve 8 . sınıf öğrencilerinin sınıf düzeyinde farklılaşmadığını bulmuştur. Gündoğdu (2013) araştırmasını yedinci ve sekizinci sınıf öğrencileriyle yapmış ve aynı sonuca ulaşmıştır. Clutts (2010) deneysel araştırmada matematik öz-yeterlik ve yaş arasında istatistiksel anlamda bir farklılık bulmamıştır. Yani yaş değiştikçe matematik öz yeterliğin değişmediğini savunmuştur. Clutts'in (2010) ulaştığ 1 bu sonuç da matematik öz yeterliğin sınıf düzeyine göre istatistiksel anlamda farklılaşmadığ 1 sonucuyla benzerdir. Alanyazında sınıf düzeyinde matematik öz yeterliğin istatistiksel anlamda değişmediğini sonucuna ulaşan araştırmalar olduğu kadar bunun aksi sonuca yani matematik özyeterliğin sınıf düzeyinde değiştiği sonucuna ulaşan araştırmalar da vardır. Çakıroğlu ve Işıksal (2009) matematik öz-yeterliğin sınıf düzeyinde anlamlı olarak farklılaştı̆̆ını bulmuştur. Adal ve Yavuz (2017) ise ortaokul öğrencilerinin matematik öz-yeterliklerinin sınıf düzeyine göre anlamlı olarak farklılaştığını bulmuştur ve öğrencilerin matematik öz-yeterliklerinin beşinci sınıftan 
sekizinci sınıfa doğru azaldığını tespit etmişlerdir. Bu araştırmada öğrencilerin sınıf seviyesi artıkça öz-yeterlik düzeyleri azalmaktadır.

Ortaokul öğrencilerinin matematiğe yönelik tutumları okulun bulunduğu mahallenin sosyoekonomik düzeyi ve öğrencilerin aylık gelirlerine göre incelenmiştir. Matematiğe yönelik tutum ve matematik öz-yeterlik içinde istatistiksel anlamda farklılık bulunmuştur. Kayseri ili Melikgazi ilçesinde bulunan orta sosyoekonomik düzeye sahip C ortaokulundaki, Kocasinan ilçesinde bulunan düşük sosyoekonomik düzeye sahip A ortaokulundaki ve İncesu ilçesinin bir köyünde bulunan B ortaokulundaki öğrencilerin matematiğe yönelik tutumları analiz edilmiştir. Okullar arasında istatistiksel olarak anlamlı fark bulunmuştur. Bu fark A ile C ve B ile C arasındadır. A ortaokulundaki öğrencilerin matematiğe yönelik tutumları $\mathrm{C}$ ortaokulundaki öğrencilerin matematiğe yönelik tutumlarından, B ortaokulundaki öğrencilerin matematiğe yönelik tutumları $\mathrm{C}$ ortaokulundaki öğrencilerin matematiğe yönelik tutumlarından yüksektir. Fakat A ile B arasında istatistiksel anlamda bir farklılık bulunmamıştır. Analiz sonucunda elde edilen sonuçlar şaşırtıcıdır; çünkü okulun sosyoekonomik düzeyi arttıkça öğrencilerin matematiğe yönelik tutumlarının artması beklenmektedir (Akdemir, 2006). Taşdemir (2010) ortaokul öğrencilerinin okudukları okulların yerleşim yerine göre incelemiştir ve ilde yaşayan öğrencilerin matematiğe yönelik tutumları ilçede yaşayan öğrencilerin matematiğe yönelik tutumlarından, ilçede yaşayan öğrencilerin matematiğe yönelik tutumları köyde yaşayan öğrencilerin matematiğe yönelik tutumlarından yüksek olduğu sonucuna ulaşmıştır. Bunun sebebinin de il ve ilçedeki olanaklardan fazla olmasından dolayı olduğunu düşünmektedir. Taşdemir (2009) okulun eğitim olanakları arttıkça matematiğe yönelik tutumun arttı̆̆ sonucuna ulaşmıştır. Araştırmanın sonucunda olanakları fazla olan okullara devam eden öğrencilerin matematiğe yönelik tutum ve öz-yeterlik ekonomik düzey değiştikçe değişmektedir.

Ortaokul öğrencilerin matematiğe yönelik tutumları aylık gelire göre incelendiğinde istatistiksel anlamda bir farklılık bulunmuştur. Bu farklılık 0-1000 TL arasında aylık geliri olan ögrenciler ile 3001-5000 TL arasındadır ve 0-1000 TL arasında aylık geliri olan öğrencilerin matematiğe yönelik tutumları daha yüksektir. 1001-3000 TL arasında aylık geliri olan öğrenciler ile 3001-5000 TL arasında aylık geliri olan öğrenciler arasında da anlamlı fark bulunmuştur ve 1001-3000 TL arasında aylık geliri olan öğrencilerin matematiğe yönelik tutumları daha yüksektir. Aylık geliri 0-1000 TL arasında olan öğrenciler ile 1001-3000 TL arasında olan öğrencilerin matematiğe yönelik tutumlarında farklılaşma yoktur. Aynı durum 0-1000 TL arasındaki öğrenciler ile 5001-7000 TL arasındaki öğrenciler için ve 3001-5000 TL arasındaki öğrenciler ile 5001-7000 TL arasındaki öğrenciler için de söz konusudur. Sonuçlara bakıldığında aylık gelirin matematiğe yönelik tutumun değişmesi için etkili bir değişken olmadığı söylenebilir. Matematiğe yönelik tutum ile aylık gelir arasında anlamlı fark olmadığını bulunmuştur (Karabacak, Ekşioğlu ve Karakış, 2019; Şimşek, Şahinkaya ve Aytekin, 2017). Fakat alanyazında aylık gelir arttıkça matematiğe yönelik tutumun arttığı sonucuna ulaşılmıştır (Çıtdır, 2019; Pehlivan, 2010; Yılmaz, 2006). Aylık gelir öğrencilerin matematiğe yönelik tutumlarını farklı yönlerde etkileyebilmektedir. $\mathrm{Bu}$ araştırmada aylık gelir öğrencilerin matematiğe yönelik tutumunu etkilememiştir.

Ortaokul öğrencilerinin matematik öz-yeterlikleri okulun bulunduğu mahallenin sosyoekonomik düzeyi ve öğrencilerin aylık gelirlerine göre incelenmiştir. Matematiğe yönelik tutum ve matematik öz-yeterlik için de istatistiksel anlamda farklılık bulunmamıştır. Kayseri ilinin Kocasinan ilçesinde bulunan düşük sosyoekonomik düzeyde olan A ortaokulunda okuyan öğrencilerin matematik öz-yeterlikleri, Kayseri ilinin İncesu ilçesinde bulunan bir köy okulu olan B ortaokulunda okuyan öğrencilerin matematik öz-yeterlikleri ve Kayseri ili Melikgazi ilçesinde bulunan orta sosyoekonomik düzeyde olan C ortaokulunda okuyan öğrencilerin matematik özyeterlikleri benzerdir. Rençber (2011) de benzer olarak öğrencilerin matematik öz-yeterliklerinin özel okul ve devlet okuluna göre farklılaşmadığını bulmuştur. Çünkü özel okul ile devlet okulunun sosyoekonomik düzeyleri farklıdır. Fakat Taşdemir (2012) matematik öz-yeterlik ile okul değişkenine göre anlamlı farklılaştığı sonucuna ulaşmıştır. Bu araştırmada öğrencilerin matematik öz-yeterlikleri aylık gelire göre değişmemektedir. 
Ortaokul öğrencilerinin matematik öz-yeterlikleri aylık gelir yani sosyoekonomik düzeye göre istatistiksel olarak anlamlı bir farklılık bulunmamıştır. Aylık geliri farklı olan öğrencilerin matematik öz-yeterlik puanları birbirine yakındır. Terzi ve Mirasyedioğlu (2009) öğrencilerin matematik öz-yeterliklerinin sosyoekonomik düzeye göre farklılaşmadığı sonucuna ulaşmıştır. Öğrencilerin matematik öz-yeterlikleri sosyo-ekonomik yapıdan ortaokul yıllarında etkilenmeyebilmektedir. Ortaokul öğrencileri sosyoekonomik seviye bizim örneklemimizde etkilenmezken farklı bir açıdan Adal ve Yavuz'un (2017) araştırmasında aylık gelir arttıkça matematik öz yeterliğin arttığı sonucuna ulaşmıştır. Ortaokul öğrencilerinin orta düzeyde sosyoekonomik seviyede olmaları öz-yeterliklerini incelerken dikkatli incelenmelidir.

Ortaokul öğrencilerinin matematiğe yönelik tutumları yazılı puanına göre incelendiğinde istatistiksel olarak bir farklılık bulunmamıştır. Bu yüzden öğrencilerin matematiğe yönelik tutumlarının benzer olması beklenir. Yüksek not alan öğrenci ile düşük not alan öğrencinin matematiğe yönelik tutumlarının benzer olmasının sebebi öğrencinin aile baskısı hissetmesi, başarısızlık korkusu, verimli çalışamaması, güdü eksikliği olabilir. Fakat alanyazında yazılı puanı arttıkça matematiğe yönelik tutumun arttığı sonucuna ulaşan araştırmalar bulunmaktadır (Duran, Sidekli ve Yorulmaz, 2018; Tan, 2015; Tuncer ve Y1lmaz, 2016). Bu araştırmaya göre matematik yazılı puanları arttıkça öğrencilerin matematiğe yönelik tutumları negatif yönde etkilenmektedir.

Ortaokul ögrencilerinin matematik öz-yeterlikleri yazılı puanına göre incelendiğinde istatistiksel olarak farklılık bulunmamıştır. Yazılı puanı düşük ve yüksek olan öğrencilerin matematik öz-yeterlik puanları birbirine yakındır. Öğrenciler matematiği başarabilme konusunda kendilerine güveniyor olabilirler yani matematik öz-yeterlikleri yüksek olabilir ama yeterli ve verimli çalışmıyor olabilirler. Bu yüzden de matematik öz-yeterliği yüksek olup yazılı puanları düşük olabilir. Ya da bu durumun tam tersi olarak öğrenciler matematiği başarabilme konusunda kendilerine güvenmiyor olabilirler yani matematik öz-yeterlikleri düşük olabilir ama çok fazla çalıştıkları için veya aile baskısı yüzünden yüksek puan alıyor olabilirler. Gündoğdu (2013) karne notu ile matematik öz-yeterlik arasında istatistiksel olarak anlamlı bir farklılık olmadığ 1 sonucuna ulaşmıştır. Fakat bu sonucun aksine alanyazındaki bazı araştırmalar yazılı notu veya karne notu arttıkça matematik öz yeterliğin arttığı sonucuna ulaşmıştır (Abalı Öztürk ve Şahin, 2015; Kurtuluş ve Öztürk, 2017; Öztürk, 2017; Uzar, 2010).

Araştırmanın son kısmında da ortaokul öğrencilerinin matematiğe yönelik tutumları ile matematik öz-yeterlikleri arasındaki ilişki incelenmiştir. Matematiğe yönelik tutum ve matematik öz-yeterlik arasında anlamlı bir ilişki olmadığı sonucuna ulaşılmıştır. Matematiğe yönelik tutum, matematik öz-yeterliği olumlu veya olumsuz şekilde ekilememektedir. Ulaşılan bu sonuç şaşırtıcıdır. Çünkü alanyazındaki araştırmalarda da olduğu gibi matematiğe yönelik tutum ve matematik öz-yeterlik arasında pozitif yönde anlamlı bir ilişkinin olması beklenmektedir (Akay ve Boz, 2011; Doruk ve diğerleri, 2016).

\section{Öneriler}

Sonuç olarak, öğrencilerin matematiğe yönelik tutumları ve matematik öz-yeterlik algılarının olumlu olmasına dikkat edilmelidir. Bu sebeple öğretmenler derste kullanacakları etkinlikleri ve materyalleri hazırlarken bu duyuşsal özellikleri göz önünde bulundurmalıdır. Sosyoekonomik yapıyı değiştirmek oldukça zordur fakat öğrencilerin üzerindeki sınav kaygılarını azaltacak rehberlik ve psikolojik destek hizmetlerinin eklenmesi önerilmektedir. Bu araştırmanın sınırlılığ Kayseri ilinin üç farklı okulunda bulunan 262 ortaokul öğrencisi ile yapılmasıdır. Gelecek araştırmaların daha büyük ve farklı bölgelerden seçilen örneklemlerle gerçekleştirilerek mevcut durumun desteklenmesi önerilmektedir. Diğer bir sınırlılı̆̆ ise araştırmanın tarama yöntemiyle yapılmasıdır. Bir sonraki araştırmalarda ilişkisel tarama yöntemi kullanılabilir. Nicel araştırma yöntemleri ile bulunan sonuçların nitel araştırma yöntemleri ile derinlemesine incelenmesi önerilmektedir. Öğrencilerin matematiğe yönelik tutumları ve matematik öz-yeterlik algılarının başarıya etkisi incelenebilir. Akademik başarısı yüksek olan öğrencilerin öz-yeterlik düzeyleri ve matematik tutumları arasındaki ilişkilerin incelenmesi önerilmektedir. Nitel araştırmalar tasarlanırken matematik başarısının matematik öz-yeterlik ile incelenmesinin yanında matematik 
öğretmenlerinin sınıf içinde matematik dersini anlatma yöntemlerinin incelenmesi de önerilmektedir.

\section{Etik Kurul Onay Bilgileri}

Bu araştırmanın Etik Kurul izni Erciyes Üniversitesi Sosyal ve Beşeri Bilimler Etik Kurulu'nun 24-03-2020 tarihli, 46 numaralı izniyle alınmıştır.

\section{Kaynaklar}

Abalı Öztürk, Y. ve Şahin, Ç. (2015). Matematiğe ilişkin akademik başarı, özyeterlilik ve tutum arasındaki ilişkilerin belirlenmesi. The Journal of Academic Social Science Studies, 31, 343-366.

Adal, A. ve Yavuz, İ. (2017). Ortaokul öğrencilerinin matematik öz yeterlik algıları ile matematik kaygı düzeyleri arasındaki ilişki. International Journal of Field Education, 3(1), 20-41.

Akay, H. ve Boz, N. (2011). Sınıf öğretmeni adaylarının matematiğe yönelik tutumları, matematiğe karşı öz yeterlik algıları ve öğretmen öz-yeterlik inançları arasındaki ilişkilerin incelenmesi. Türk Eğitim Bilimleri Dergisi, 9(2), 281-312.

Akdemir, Ö. (2006). Illköğretim öğrencilerinin matematik dersine yönelik tutumları ve başarı güdüsü (Yayımlanmamış yüksek lisans tezi). Dokuz Eylül Üniversitesi, İzmir.

Alkan, H., Güzel, E. B. ve Elçi, A. N. (2004). Öğrencilerin matematiğe yönelik tutumlarında matematik öğretmenlerinin üstlendiği rollerin belirlenmesi. XIII. Ulusal eğitim bilimleri kurultayl, 6-9.

Ary, D., Jacobs, L. C., Sorensen, C. ve Razavieh, A. (2010). Introduction to research in education eight edition. USA: Wadsworth.

Aşkar, P. ve Umay, A. (2001). İlköğretim matematik öğretmenliği öğrencilerinin bilgisayarla ilgili öz-yeterlik algısı. Hacettepe Üniversitesi Ĕgitim Fakültesi Dergisi, 21(21), 1-8.

Bandura, A. (1997). Self-efficacy: The exercise of control. New York, Freeman.

Baykul, Y. (1990). Illkokul beşinci sınıftan lise ve dengi okulların son sinıflarına kadar matematik ve fen derslerine karşı tutumda görülen değişmeler ve öğrenci seçme sinavindaki başarı ile ilişkili olduğu düşünülen bazı faktörler. ÖSYM Yayınları, Ankara.

Birgin, O. ve Demirkan, H. (2017). Yatılı bölge ortaokulu öğrencilerinin matematiğe yönelik tutumlarının bazı değişkenler bakımından incelenmesi. E-uluslararası Eğitim Araştırmaları Dergisi, 8(2), 1-15.

Clutts, D. W. (2010). Mathematics self-efficacy of community college students in developmental mathematics courses (Yayımlanmamış doktora tezi). Liberty University, Lynchburg, Virginia, Amerika.

Çakıroğlu, E. ve Işıksal, M. (2009). Preservice elementary teachers' attitudes and self-efficacy beliefs toward mathematics. Eğitim ve Bilim, 34(151), 132-139.

Çavdar, D. (2019). Matematik dersinde akademik başarı, öz yeterlik ve matematik dersine yönelik tutum arasındaki ilişkinin incelenmesi (Yayımlanmamış yüksek lisans tezi). Balıkesir Üniversitesi, Balıkesir.

Çelik, H. C. ve Bindak, R. (2005). Sınıf öğretmenliği bölümü öğrencilerinin matematiğe yönelik tutumlarının çeşitli değişkenlere göre incelenmesi. Kastamonu Ĕgitim Dergisi, 13(2), 427-436.

Çıtdır, N. (2019). Ortaokul öğrencilerinin matematiğe yönelik tutumlarının incelenmesi (Yayımlanmamış yüksek lisans tezi). Marmara Üniversitesi, İstanbul.

Doruk, M., Öztürk, M. ve Kaplan, A. (2016). Ortaokul öğrencilerinin matematiğe yönelik özyeterlik algılarının belirlenmesi: Kaygı ve tutum faktörleri. Adlyaman Üniversitesi Eğitim Bilimleri Dergisi, 6(2), 283-302.

Duran, C., Sidekli, S. ve Yorulmaz, A. (2018). İlkokul dördüncü sınıf öğrencilerinin matematik etkinliklerine yönelik tutumlarının incelenmesi. International Primary Education Research Journal, 2(1), 17-26. 
Erdoğan, A., Baloğlu, M. ve Kesici, Ş. (2011). Gender differences in geometry and mathematics achievement and self-efficacy beliefs in geometry. Eurasian Journal of Educational Research, 43, 91-106.

Fraenkel, J. R., Wallen, N. E. ve Hyun, H. H. (2011). How to design and evaluate research in education. New York: McGraw-Hill Humanities/Social Sciences/Languages.

Goodwin, K. S., Ostrom, L. ve Scott, K. W. (2009). Gender differences in mathematics selfefficacy and back substitution in multiple-choice assessment. Journal of Adult Education, $38(1), 22-42$.

Gülburnu, M. ve Yıldırım, K. (2015). İlkokul ve ortaokul öğrencilerine yönelik matematik tutum ölçeği geliştirilmesi ve uygulanması. VI. Uluslararası Türkiye Eğitim Araştırmaları Kongresi, içinde (ss. 568-581). Ankara,

Gündoğdu, S. (2013). 7. ve 8. sinıf ögrencilerinin sahip olduğu matematiksel güç ile matematik öz yeterliği arasındaki iliş̧ki (Yayımlanmamış yüksek lisans tezi). Eskişehir Osmangazi Üniversitesi, Eskişehir.

Hackett, G. ve Betz, N. E. (1989). An exploration of the mathematics self-efficacy/mathematics performance correspondence. Journal for Research in Mathematics Education, 20(3), 261-273.

Hart, L. (1989). Describing the affective domain: Saying what we mean. D. B. McLeod ve V. M. Adams (Yay. haz.). Affecting and mathematical problem solving. New York, NY: Springer New York. doi:10.1007/978-1-4612-3614-6

Karabacak, K., Ekşioğlu, S. ve Karakış, N. (2016). Examination of attitudes of secondary school 6 th class students related to their attitudes towards maths in the frame of several variables. Journal of Human Sciences, 13(1), 1937-1944.

Karaduman, B. (2018). Ortaokul 6. ,7. ve 8. sinıf ögrencilerinin orantısal akll yürütme becerilerini ve matematik dersine yönelik tutumlarının bazı değişkenler açısından incelenmesi: cinsiyet ve sinıf düzeyi perspektifi (Yayımlanmamıs yüksek lisans tezi). Başkent Üniversitesi, Ankara.

Katranc1, Y. ve Şengül, S. (2019). Ortaokul öğrencilerinin matematik problemi oluşturma, matematik problemi çözme ve matematiğe yönelik tutumları arasındaki ilişkiler. Eğitim ve Bilim, 44(197), 1-24.

Koca, S. (2011). Illköğretim 8. sinıf öğrencilerinin matematik başarl, tutum ve kaygllarının ögrenme stillerine göre farklıllğının incelenmesi (Yayımlanmamış yüksek lisans tezi). Afyon Kocatepe Üniversitesi, Afyonkarahisar.

Kurtuluş, A. ve Öztürk, B. (2017). Ortaokul öğrencilerinin üstbilişsel farkındalık düzeyi ile matematik öz yeterlik algısının matematik başarısına etkisi. Dicle Üniversitesi Ziya Gökalp Ë̆itim Fakültesi Dergisi, 31, 762-778.

Milli Eğitim Bakanlığı (MEB) (2018). Ortaokul matematik dersi (5, 6, 7 ve 8. Sinıflar) ögretim programı. Ankara: Talim ve Terbiye Kurulu Başkanlığı.

Neale, D. C. (1969). The role of attitudes in learning mathematics. The Arithmetic Teacher, 16(8), 631-640.

Oğuz, A. ve Kutlu-Kalender, M. D. (2018). Ortaokul öğrencilerinin üst bilişsel farkındalıkları ile öz yeterlik algıları arasındaki ilişki. Eğitimde Kuram ve Uygulama, 14(2), 170-186. doi:10.17244/eku.319267.

Öztürk, B. (2017). Ortaokul ögrencilerinin üstbilişsel farkındalık düzeyi ile matematik öz yeterlik algisının matematik başarısına etkisinin incelenmesi (Yayımlanmamış yüksek lisans tezi). Eskişehir Osmangazi Üniversitesi, Eskişehir.

Öztürk, B. ve Kurtuluş, A. (2017). Ortaokul öğrencilerinin üstbilişsel farkındalık düzeyi ile matematik öz yeterlik algısının matematik başarısına etkisi. Dicle Üniversitesi Ziya Gökalp Ĕ̈itim Fakültesi Dergisi, 31, 762-778.

Pajares, F. (1996). Self-efficacy beliefs in academic settings. Review of Educational Research, 66(4), 543-578. 
Pehlivan, H. (2010). Ankara Fen Lisesi öğrencilerinin matematik dersine yönelik tutumları ile akademik benlik tasarımlarının bazı ailesel faktörler açısından incelenmesi. Kastamonu Ĕ̈itim Dergisi, 18(3), 805-818.

Pehlivan, F. (2012). Illköğretim beşinci sınıf matematik dersinde üstbiliş strateji kullanımının ögrencilerin başarı ve tutumlarına etkisi (Yayımlanmamış yüksek lisans tezi). Niğde Üniversitesi, Niğde.

Rençber, Ş. (2011). An investigation of the relationship among the seventh grade students' mathematics self efficacy, mathematics anxiety, attitudes towards mathematics and mathematics achievement regarding gender and school type (Yayımlanmamış yüksek lisans tezi). Middle East Technical University, Ankara.

Sevgi, S. ve Orman, F. (2020). An investigation, based on some variables, into the attitudes of middle school students towards mathematics and metacognitive skills. Elementary Education Online, 19(1), 183-197.

Şimşek, H., Şahinkaya, N. ve Aytekin, C. (2017). İlköğretim öğrencilerinin matematik kaygılarının ve matematik dersine yönelik tutumlarının çeşitli değişkenler açısından incelenmesi. Necatibey Ĕgitim Fakültesi Elektronik Fen ve Matematik Eğitimi Dergisi, 11(2), 82-108.

Takır, A. (2018). Sınıf öğretmenlerinin matematik öğretimine yönelik öz-yeterlilik inançlarının incelenmesi. International Journal of Social Science Research, 7(1), 141-153.

Tan, M. N. (2015). Ortaokul öğrencilerinin matematik kaygısı öğrenilmişs çaresizlik ve matematiğe yönelik tutum düzeyleri arasındaki ilişkilerin incelenmesi (Yayımlanmamış yüksek lisans tezi). Necmettin Erbakan Üniversitesi, Konya.

Taşdemir, C. (2009). İlköğretim ikinci kademe öğrencilerinin matematik dersine karşı tutumları: Bitlis ili örneği. Dicle Üniversitesi Ziya Gökalp Ĕ̈itim Fakültesi Dergisi, 12, 89-96.

Taşdemir, C. (2010). İlköğretim 6, 7 ve 8. sinıf öğrencilerinin matematik dersine yönelik tutumlarının bazı değişkenlere göre belirlenmesi: Bitlis ili örneği. Atatürk Üniversitesi Kazım Karabekir Eğitim Fakültesi Dergisi, 17, 285-501.

Taşdemir, C. (2012). Lise son sınıf öğrencilerinin matematik öz-yeterlik düzeylerinin bazı değişkenler açısından incelenmesi (Bitlis ili örneği). Karadeniz Fen Bilimleri Dergisi, $3(1), 39-50$.

Terzi, M. ve Mirasyedioğlu, Ş. (2009). İlköğretim matematik öğretmen adaylarının matematiğe yönelik özyeterlik algılarının bazı değişkenler açısından incelenmesi. TÜBAV Bilim, 2(2), 257-265.

Tuncer, M. ve Yılmaz, Ö. (2016). Ortaokul öğrencilerinin matematik dersine yönelik tutum ve kaygılarına ilişkin görüşlerinin değerlendirilmesi. Kahramanmaraş Sütçü İmam Üniversitesi Sosyal Bilimler Dergisi, 13(2), 47-64.

Umay, A. (2001). İlköğretim matematik öğretmenliği programının matematiğe karş1 özyeterlik algisina etkisi [The effect of the primary school mathematics teaching program on the mathematics self-efficacy of students]. Journal of Qafqaz University, 8(4), 37-44.

Ural, A. (2007). İşbirlikli öğrenmenin matematikteki akademik başarıya, kalıcıllğa, matematik özyeterlilik algısına ve matematiğe karşı tutuma etkisi (Yayımlanmamış doktora tezi). Gazi Üniversitesi, Ankara.

Ural, A., Umay, A. ve Argün, Z. (2008). Öğrenci takımları başarı bölümleri tekniği temelli eğitimin matematikte akademik başarı ve öz yeterliğe etkisi. Hacettepe Üniversitesi Ĕ̈itim Fakültesi Dergisi, 35(35), 307-318.

Uzar, F. N. (2010). İlköğretim öğrencilerinin matematik dersine yönelik öz-yeterliğini besleyen kaynakların farklı değişkenlere göre incelenmesi (Yayımlanmamış yüksek lisans tezi). Hacettepe Üniversitesi, Ankara.

Yavuz-Mumcu, H. ve Aktaş-Cansız, M. (2015). Multi-program high school students' attitudes and self-efficacy perceptions toward mathematics. Eurasian Journal of Educational Research, 15(59), 207-226. 
Yenilmez, K. ve Özabac1, N. Ș. (2003). Yatılı öğretmen okulu öğrencilerinin matematik ile ilgili tutumları ve matematik kaygı düzeyleri arasındaki ilişki üzerine bir araştırma. Pamukkale Üniversitesi Ĕ̈itim Fakültesi Dergisi, 2(14), 132-144.

Yıldız, S. (2006). Üniversite sinavina hazırlanan dershane ögrencilerinin matematik dersine karşı tutumları (Yayımlanmamış yüksek lisans tezi). Hacettepe Üniversitesi, Ankara.

Yılmaz, B. (2006). Beşinci sinıf ögretmenlerinin fen ve teknoloji dersinde yapılandırmacı ögrenme ortamı düzenleme becerileri (Yayımlanmamış yüksek lisans tezi). Yıldız Teknik Üniversitesi, İstanbul.

Yürekli, Ü. B. (2008). Sinıf ögretmeni adaylarının matematiğe yönelik öz-yeterlik algıları ve tutumları arasındaki ilişki (Yayımlanmamış yüksek lisans tezi). Pamukkale Üniversitesi, Denizli.

Zan, R. ve Martino, P. D. (2007). Attitude toward mathematics: overcoming the positive/negative dichotomy. The Montana Mathematics Enthusiast, 3(1), 157-168.

\section{Extended Abstract \\ Introduction}

The development of some basic skills for learning and using mathematics effectively is aimed in middle school mathematics curriculum as well as gaining mathematical concepts. Basic skills are defined as problem solving, reasoning, association, communication and affective skills (Ministry of National Education (MoNE), 2018). Affective skills are defined as students' positive attitude towards mathematics, having self-confidence, having mathematical values, self-regulation skills and self-efficacy skills (MoNE, 2018). Aim of this study was to analyze the mathematics selfefficacy and attitudes of students studying at 5 th, 6 th, 7 th and 8 th grades towards mathematics in Turkey on gender, grade level, school, monthly income and exam scores. Second aim was to analyze whether or not there was a significant relationship between attitude towards mathematics and mathematics self-efficacy.

\section{Method}

The method of the research was the survey model, one of the quantitative research methods. The sample of the study was 262 students which were 111girls (42.4\%) and $151(56.7 \%)$ were boys. In the sample, there were $78(29.8 \%) 5_{\text {th }}, 64(24.4 \%) 6$ th, $68(26.0 \%) 7_{\text {th }}$ and $52(19.8 \%) 8_{\text {th }}$ grade students. When the distribution of middle school students according to their schools was examined, 99 students (37.8\%) were in A middle school and 80 students (30.5\%) were in B middle school and 83 students $(31.7 \%)$ were in $\mathrm{C}$ middle school. When the distribution of middle school students according to their monthly income was analyzed, 45 students' (17.2\%) monthly income was in the range of 0-1000 TL, 98 students' (37.4\%) monthly income was in the range of 10013000 TL, 57 students' (21.8\%) monthly income was in the range of 3001-5000 TL, and the monthly income of 29 students' (11.1\%) was in the range of 5001-7000 TL. Students' who did not mark their monthly income was $33(12.6 \%)$. When the exam scores of middle school students in the first semester of 2019-2020 were analyzed, 12 students (4.6\%) were scored between 0-49, 64 students $(24.4 \%)$ were scored between 50-69, 111 students (42.4\%). It is seen that in the range of 70-90, 48 students (18.3\%) scored were in the range of 91-100. In addition, 27 students (10.3\%) did not appear to be marked. In this research, "Mathematics Self-efficacy Perception Scale" developed by Umay (2001) and "Attitude Scale towards Mathematics Course" developed by Baykul (1990) to determine mathematics self-efficacy perception levels of middle school students were used. Both scales were five-point Likert type.

\section{Result and Discussion}

Girl ( $\mathrm{p}=0.000)$ and boy $(\mathrm{p}=0.020)$ students were not distributed normally in the attitude scale towards mathematics. In the mathematics self-efficacy scale, girl (0.005) and boy (0.000) students were not distributed normally. In the Mann-Whitney U test, there was no statistically significant difference between girls and boys $[\mathrm{U}=7979 ; \mathrm{z}=-0.663 ; \mathrm{p}=0.507>0.05]$. There was no statistically significant difference between mathematics self-efficacy of girl and boy students as 
a result of Mann-Whitney $U$ test $[U=7930 ; z=-, 745 ; p=457>0.05]$. Attitudes of middle school students towards mathematics did not differ according to gender. There were studies that conclude that the attitude towards mathematics did not differ by gender (Birgin \& Demirkan, 2017; Çavdar, 2019; Karaduman, 2018; Koca, 2011; Sevgi \& Orman, 2020; Tuncer \& Y1lmaz, 2016). These studies support the conclusion that boy and girl students' attitudes towards mathematics were similar. However, contrary to these studies, there were also studies that have reached the conclusion that the attitudes of middle school students towards mathematics differ according to gender. In general, it was concluded that this difference was in favor of girls, that is, girls 'attitudes towards mathematics were higher than boys' attitudes towards mathematics (Çelik \& Bindak, 2005; Katranc1 \& Şengül, 2019). Pehlivan (2012) concluded that boys 'attitudes towards mathematics were higher than girls' attitudes towards mathematics middle schools.

Kruskal-Wallis test was conducted in which middle school students' mathematics selfefficacy was not distributed normally at the grade levels. Attitudes of middle school students towards mathematics differ statistically at the grade levels [Kruskal-Wallis $=9,814 ; \mathrm{df}=3 ; \mathrm{p}=$ $0.020<0.05]$. However, mathematics self-efficacy of middle school students did not differ statistically at the grade levels [Kruskal-Wallis $=0.942 ; \mathrm{df}=3 ; \mathrm{p}=0.812<0.05$ ]. Middle school students' perceptions of mathematics self-efficacy did not differ significantly according to gender. Perceptions of girl and boy students participating in the research were similar in mathematics selfefficacy. Perception of mathematics self-efficacy did not differ by gender (Akay \& Boz, 2011; Goodwin, Ostrom \& Scott, 2009; Öztürk \& Kurtuluş, 2017; Öztürk, 2017; Takır, 2018). On the other hand, there were also studies that conclude that the perception of mathematics self-efficacy differs significantly by gender (Adal \& Yavuz, 2017; Rençber, 2011; Oğuz \& Kutlu-Kalender, 2018). Researchers found a significant difference between the self-efficacy perceptions of girls and boys and this difference is in favor of boys (Adal \& Yavuz, 2017; Rençber, 2011). In their study with Oğuz and Kutlu-Kalender (2018) middle school students, there was a difference between the mathematics self-efficacy of girl and boy students, and perceptions of girl students' mathematics self-efficacy are higher than that of boys. The reason why the studies in the literature were different from each other may be that the samples of the research are different, the readiness of the participants in the research is different or the scales used were different.

There was no statistical difference between the averages of $5_{\text {th }}-6_{\text {th }}$ grade and $7_{\text {th }}-8_{\text {th }}$ grade students' attitudes towards mathematics. A statistically significant mean difference was found between the attitudes of $5_{\text {th }}-7_{\text {th }}$ graders and 5 th -8 th graders and 6 th $-7_{\text {th }}$ graders towards mathematics. According to the results of Kruskal-Wallis analysis, middle school students' attitudes towards mathematics differ statistically significantly compared to schools since middle school students did not distribute normally according to schools [Kruskal-Wallis $=7,836 ; \mathrm{df}=2$ : $\mathrm{p}=0.020<0.05]$. However, mathematics self-efficacy of middle school students did not differ statistically compared to schools [Kruskal-Wallis $=0,383 ; \mathrm{df}=2: \mathrm{p}=0.826<0.05$ ]. There was no statistical difference between the attitudes of students studying in A and B middle school towards mathematics. A statistically significant difference was found between the attitudes of students studying in A-C and B-C middle school towards mathematics.

Kruskal-Wallis analysis was carried out as the attitudes and mathematics self-efficacy of middle school students towards mathematics did not spread normally according to monthly income. Middle school students' attitude scores towards mathematics differed statistically according to the monthly income variable [Kruskal-Wallis $=8,287 ; \mathrm{df}=3: \mathrm{p}=0.040<0.05$ ]. There was no statistically significant difference between the mathematics self-efficacy scores of the middle school students with different monthly income [Kruskal- Wallis $=8,287 ; \mathrm{df}=3: \mathrm{p}=$ $0.184>0.05]$.

There was no statistically significant difference between the students whose monthly income was between 0-1000 TL and students with 5001- $7000 \mathrm{TL}$ attitude towards mathematics [Mann Whitney $\mathrm{U}=523,5 ; \mathrm{z}=-1.43 ; \mathrm{p}=0.153>0.05$ ]. There was a statistically significant difference between students with monthly income between 1001-3000 TL and students with 3001- 5000 TL attitudes towards mathematics [Mann Whitney $\mathrm{U}=2140,5 ; \mathrm{z}=-2.423 ; \mathrm{p}=0.015$ $<0.05]$. There was no statistical difference between students with monthly income between 1001- 
$3000 \mathrm{TL}$ and students with 5001- $7000 \mathrm{TL}$ attitudes towards mathematics [Mann Whitney $\mathrm{U}=$ $1142 ; z=-1,604 ; p=0.109>0.05]$. Finally, there was no statistical difference between students with monthly income between 3001-5000 TL and students with 5001- $7000 \mathrm{TL}$ attitudes towards mathematics [Mann Whitney $\mathrm{U}=804,5 ; \mathrm{z}=-0.201 ; \mathrm{p}=0.840>0.05$ ].

In Kruskal-Wallis analysis, there was no statistically significant difference in the attitudes of middle school students towards mathematics according to the exam scores [Kruskal-Wallis $=$ $0,146 ; \mathrm{df}=3 ; \mathrm{p}=0986>0.05]$. As students' exam scores change, their mathematics self-efficacy averages change mathematically. However, there was no statistically significant mean difference between middle school students' exam scores and mathematics self-efficacy $[F(4,257)=0.995$; $\mathrm{p}=0.431<0.05]$. When the results of Spearman correlation analysis conducted to determine whether there was a significant relationship between students 'attitudes towards mathematics and mathematics self-efficacy, there was no relationship between students' mathematics self-efficacy and attitudes towards mathematics $[\mathrm{r}=-0.062 ; \mathrm{p}=0.302]$. The attitudes of middle school students towards mathematics were examined according to the grade levels and a statistical difference was found between the grade levels. The difference in attitude towards mathematics was between 5 th and $7_{\text {th }}$ grade, between 5 th and 8 th grade, and between 6 th and $7_{\text {th }}$ grade.

The attitude of 5th grade students towards mathematics was higher than the attitude of 7 th grade students towards mathematics. Similarly, 5th grade students' attitudes towards mathematics were higher than 8th $_{\text {th }}$ grade students' attitudes towards mathematics. Finally, 6th grade students' attitudes towards mathematics are higher than 7 th grade students' attitudes towards mathematics. However, the attitude towards mathematics did not differ between 5 th and 6 th grades and between 7 th and 8 th grades. According to the results obtained, the attitude towards mathematics decreases as the grade level increases. There were studies supporting this result (Çıtdır, 2019; Tan, 2015; Gülburnu \& Yıldırım, 2015; Katrancı \& Şengül, 2019; Taşdemir, 2009). Researchers agree that the attitude towards mathematics decreases as the grade level increases. The reasons for this may be that as the grade level increases, exam anxiety towards national exams increases or issues become difficult.

When the mathematics self-efficacy perceptions of middle school students were examined according to the grade level, there was no statistically significant difference between the grade levels. Self-efficacy did not change as the grade level increased. Uzar (2010) found in his research with 6th, $7_{\text {th }}$ and 8 th grades that 6 th, $7_{\text {th }}$ and $8_{\text {th }}$ grade students did not differ at the grade level. Gündoğdu (2013) conducted his research with 7 th and 8 th grade students and reached the same result. According to Gündoğdu (2013), there was no statistical significant difference in mathematics self-efficacy grade level of students. In his experimental study, Clutts (2010) did not find any statistical difference between mathematics self-efficacy and age. In other words, mathematics argued that self-efficacy did not change as age changes. This result reached by Clutts (2010) was similar to the result that mathematics self-efficacy did not differ statistically according to grade level. Self-efficacy of mathematics at the grade level did not change statistically. 